Leibniz-Institut für

Wirtschaftsforschung

Halle

\title{
Banks and Sovereign Risk: A Granular View
}

Claudia M. Buch Michael Koetter Jana Ohls

September 2015

No. 12

\section{IWH-DISKUSSIONSPAPIERE IWH DISCUSSION PAPERS}


Authors: Claudia M. Buch

Deutsche Bundesbank

Michael Koetter (corresponding author)

Halle Institute for Economic Research (IWH)

Department of Financial Markets

E-mail: Michael.Koetter@iwh-halle.de

Phone: +49345 7753820

Frankfurt School of Finance \& Management

E-mail:m.koetter@fs.de

Phone: +4969154008446

\section{Jana Ohls}

Deutsche Bundesbank

E-mail: jana.ohls@bundesbank.de

The responsibility for discussion papers lies solely with the individual authors. The views expressed herein do not necessarily represent those of the IWH. The papers represent preliminary work and are circulated to encourage discussion with the authors. Citation of the discussion papers should account for their provisional character; a revised version may be available directly from the authors.

Comments and suggestions on the methods and results presented are welcome.

IWH Discussion Papers are indexed in RePEc-EconPapers and in ECONIS.

Editor:

Halle Institute for Economic Research (IWH) - Member of the Leibniz Association

Address: $\quad$ Kleine Maerkerstrasse 8, D-06108 Halle (Saale), Germany

Postal Address: P.O. Box 1103 61, D-06017 Halle (Saale), Germany

Phone: $\quad$ +49345775360

Fax: $\quad+493457753820$

Internet: $\quad$ www.iwh-halle.de

ISSN $1860-5303$ (Print)

ISSN 2194-2188 (Online) 


\title{
Banks and Sovereign Risk: A Granular View*
}

\begin{abstract}
We identify the determinants of all German banks' sovereign debt exposures between 2005 and 2013 and test for the implications of these exposures for bank risk. Larger, more capital market affine, and less capitalised banks hold more sovereign bonds. Around $15 \%$ of all German banks never hold sovereign bonds during the sample period. The sensitivity of sovereign bond holdings by banks to eurozone membership and inflation increased significantly since the collapse of Lehman Brothers. Since the outbreak of the sovereign debt crisis, banks prefer sovereigns with lower debt ratios and lower bond yields. Finally, we find that riskiness of government bond holdings affects bank risk only since 2010.This confirms the existence of a nexus between government debt and bank risk.
\end{abstract}

Keywords: sovereign debt; bank-level heterogeneity; bank risk

JEL Classification: G01, G11, G21

* This paper is an updated version of Deutsche Bundesbank Discussion Paper 29/2013 and was partly written during visits by the authors to the Research Centre of the Deutsche Bundesbank. The hospitality of the Bundesbank as well as access to its bank-level financial accounts and Securities Holdings Statistics databases are gratefully acknowledged. We are grateful for feedback received from two anonymous referees as well as from Marco Pagano, Alexander Popov and participants at the Securities Holdings Statistics workshop at the Deutsche Bundesbank, the 2012 doctoral workshop at the HelmutSchmidt-University, the 2012 SUERF Colloquium, the 2012 CREDIT conference and the 2013 EMGESRC workshop at Cass Business School. We would like to thank Markus Amann for assisting in our data access. Daniel Budde has provided most efficient research assistance. Any errors and inconsistencies are solely our own responsibility. The paper represents the authors' personal opinions and does not necessarily reflect the views of the Deutsche Bundesbank or its staff. 


\section{Motivation}

The financial crisis revealed the need for an improved understanding of banks' investments in sovereign bonds and of the impact of these investments on bank risk. Previous research has focused on the determinants of sovereign bond spreads or the evolution of CDS spreads, that is on the pricing of sovereign debt. Research on the determinants of the volume of banks' sovereign debt exposures and the impact of sovereign bond exposures on risk at banks is more limited. This is the gap that we fill with this paper.

We employ detailed bank-level panel data from the Deutsche Bundesbank's Securities Holdings Statistics for all German banks to investigate why banks hold sovereign bonds and how these exposures affect bank risk. These novel micro data provide information on banks' entire security portfolios, including sovereign bonds, bank-by-bank, and security-by-security. The data are available per quarter from Q4:2005 until Q3:2013, thus covering regular times, the turmoil around the demise of Lehman Brothers, and the sovereign debt crisis in the eurozone. The level of detail in the data allows analysing the sovereign risk exposures of all German banks. We thus complement important studies that are confined to selected samples of large banks, such as those covered by the stress tests of the European Banking Authority (EBA) analysed by Acharya and Steffen (2015). We combine these sovereign bond portfolio data with detailed micro-prudential supervisory and issuer-country data.

An important stylized fact of the data camouflaged in selected samples of large banks only is that a significant fraction of German banks, namely $15 \%$, do never hold sovereign bonds during the entire sample period (see Figure 1). Another $25 \%$ of all German banks always hold some kind of sovereign debt. The remaining banks enter and exit the sovereign debt market continuously, underpinning the importance of this asset class as a channel of active asset management. Participation rates in sovereign bond markets also vary across banking groups and over time (see Figure 2).

German banks not only differ with regard to their activity on the government bond market, their level of exposure also differs considerably (see Figure 3). For the average German bank, sovereign exposures are not very important as sovereign bonds account for only $5 \%$ of total assets for all German banks. However, this number ranges from 3.5\% for commercial banks to $13 \%$ for mortgage banks.

Our empirical model explains observed sovereign debt exposures and their impact on bank risk in two steps. First, we specify a Heckman selection model to estimate the likelihood that banks hold certain sovereign bonds and how much they hold conditional on this selection choice. Regarding bank-level determinants of sovereign debt exposures, balance sheet growth and lower capitalization are associated with higher holdings of sovereign bonds. If banks become more affine to capital markets, as reflected by a more intensive use of market-based 
funding, larger security, and smaller customer loan portfolios, they hold more sovereign bonds. Country characteristics play a role in the investment decisions of banks as well: German banks hold more bonds from large, low-inflation, and highly indebted countries from the eurozone. They are less exposed to high-yield countries, which borrowed from IMF programs. Importantly, banks have reacted to changing macroeconomic and risk factors both after the collapse of Lehman Brothers as well as with the outbreak of the sovereign debt crisis. After the collapse, we observe a restructuring in sovereign bond portfolios in response to macroeconomic fundamentals with massive reductions of debt from eurozone periphery countries towards the home market (see Figures 3 and 4).

In a second step, we assess the impact of sovereign bond holdings on bank risk. We use predicted rather than observed bond exposures as a function of issuer country-specific macro factors and of bank-specific covariates to account explicitly for selection bias in the data. Indicators of bank risk are derived from annual microprudential financial accounts. We aggregate predicted sovereign exposures per year across issuer country and classify low, medium, and high risk bonds based on sovereign ratings. The identifying assumption is thus that an individual bank's annual average risk and average macro conditions of individual countries are independent. The main measure of bank risk is the $z$-score calculated from supervisory financial accounts data reported to the Deutsche Bundesbank, which enables us to gauge the risk of the German banking population. This comprehensive coverage is an important advantage compared to market-based measures of risk, which we consider for robustness as well but that are confined to a much smaller number of German banks.

Overall, we find an adverse impact of exposures towards relatively risky sovereign bonds (rated BBB or worse) on bank risk. For our main measure of bank risk, these effects are statistically significant after the outbreak of the financial crisis. Larger predicted volumes of low risk government bonds decrease the risk of banks. Larger exposures to risky government bonds increase, in turn, bank risk significantly. This result is confirmed when considering CDS spreads and non-performing loans as alternative risk measures. This confirms the existence of a nexus between sovereign debt holdings and bank risk documented for large banks before (Acharya and Steffen 2015).

We contribute to a growing literature on the link between banks and sovereign risk. Banks hold sovereign debt for a variety of reasons such as a desire to hold diversified asset portfolios (Rochet 2008), as collateral for interbank refinancing operations (Bolton and Jeanne 2011), as a means to generate liquidity (Gennaioli et al. 2014), or due to moral suasion of governments (Becker and Scharfstein 2014). Especially during twin banking and sovereign debt crisis, it can be optimal for governments if banks hold domestic government debt and remain undercapitalized (Crosignati 2014). In fact, periphery countries in the eurozone exerted moral suasion to induce their banks to hold sovereign debt (Battistini et al. 2014, Becker and Ivashina 2014). Our empirical model is a reduced form approach that exploits the substantial 
variation across the different business models by commercial, savings and cooperative banks in Germany (Koetter 2013, Krahnen und Schmidt 2004).

The paper closest to ours is Hildebrand et al. (2012) who employ the same database that we use to analyse the entire security portfolios of banks, not just sovereign bonds. They find that, during the crisis, banks increased the share of domestic sovereign bonds in their portfolio. We complement their analysis because we control for selection bias, we analyse the impact of country-level determinants on sovereign bond exposures, and we assess the impact on bank risk of these holdings.

In a related paper, Beber et al. (2009) use data from pre-crisis eurozone sovereign bond markets to analyse the demand for sovereign bonds. They find that credit quality matters for the valuation of bonds and that liquidity matters for investment decisions in periods of financial stress. Their data do not permit an analysis of the effects of investor characteristics, which is our focus. Bai et al. (2012) study the period since 2006 and find that, during the early crisis period, liquidity risk mattered for bond spreads but, during the later stages of the crisis, credit risk mattered. De Grauwe and Yi (2012) argue that government bonds in the eurozone were mispriced before the crisis. Our results are consistent with these findings to the extent that macroeconomic determinants of sovereign bond holdings are largely insignificant prior to the Lehman failure, but not thereafter. We complement these studies by analysing volume rather than price effects and by controlling for investor (bank) characteristics.

Acharya and Steffen (2015) use stock prices and EBA stress test data to analyse the sovereign bond holdings of banks. They find that eurozone banks engage in carry trades by borrowing money at low interest rates and by investing into high-yield sovereign bonds. In line with our results, they find that large, weakly capitalised banks with higher short-term debt are more active in these trades. Battistini et al. (2014) use the EBA stress test data to study the home bias in banks' sovereign portfolios. They find that Euro periphery banks increase their domestic sovereign exposure when idiosyncratic sovereign risk rises, while banks from core countries do not. They interpret this result as evidence for moral suasion by governments or carry trade behaviour of Euro periphery banks. Banks from core as well as from periphery countries increased investment into domestic sovereign bonds if common sovereign risk increases. We differ in three important respects. First, we analyse all banks active in Germany, thereby circumventing selection bias that plagues prior studies confined to listed banks. Second, we use information on the sovereign bond exposure to all OECD countries. Third, our study sheds light on the impact of sovereign bond exposures on bank risk.

A number of studies analyse the impact of sovereign risk on banks' credit default swaps (CDS), albeit at fairly aggregate levels. Acharya et al. (2014) analyse the two-way feedback between sovereign and financial sector risk using data on bank CDS for the eurozone countries. For the years 2007-2010, they find that announcements of financial sector bailouts affected sovereign CDS spreads and narrowed bank CDS spreads. After the bailouts took place, bank and sovereign risk co-moved. Alter and Schüler (2012) also consider co- 
movements in sovereign CDS spreads and national bank default risk for selected eurozone countries during the same period. They report that bank default risk impacts sovereign risk prior to bank bailouts, an effect that becomes stronger in the short run after a bailout, but becomes insignificant in the longer run. Alter and Beyer (2014) investigate the period of the sovereign debt crisis between October 2009 and July 2012 and also confirm a relationship between sovereign and bank default risk for aggregate CDS spreads. Our paper adds to this evidence by analysing an entire banking system during different phases of the banking and sovereign debt crises.

Angeloni and Wolff (2012) analyse the impact of sovereign bond holdings on banks' share prices using data provided by the European Banking Authority (EBA). They find that the effects of banks' sovereign debt holdings vary depending on the period: Greek sovereign debt affected banks' market values between July and October 2011 but not after October 2011. Their study differs from ours because the EBA stress test data provide cross-sectional information only for a small number of large European banks, whereas we use panel information for all German banks.

Ang and Longstaff (2013) complement European default risk studies by comparing systemic and credit market shocks in the eurozone to those in the U.S.. Based on CDS spreads of different sovereigns, they report that systemic risk is much higher among individual eurozone countries compared to U.S. states and that credit market shocks drive sovereign risk more than poor macroeconomic fundamentals.

In sum, the main difference of our paper compared to this rapidly growing body of literature is to investigate the effect of European sovereign debt for a comprehensive sample of listed and non-listed banks in a large EMU economy during both crisis and regular times. By analysing the determinants of sovereign bond holdings and their impact on bank risk, we complement previous studies that mostly focus on the relationship between bank-level outcomes and the pricing of sovereign default risk.

The remainder of the paper is structured as follows. In section 2, we present the data and descriptive statistics for German banks' sovereign bond holdings. In section 3, we turn analyse the determinants of banks' investments in sovereign bonds. In section 4 , we analyse the impact of these sovereign bond holdings on bank risk. Section 5 concludes.

\section{German banks and their securities' holdings}

\subsection{Sampled banks}

Our main interest pertains to the determinants and the risk effects of banks' sovereign bond holdings, which are reported to the Securities Holdings Statistics of the Deutsche Bundesbank 
by each bank located in Germany (Amann et al. 2012). ${ }^{1}$ We follow the taxonomy of the Deutsche Bundesbank and include banks from the three banking pillars (commercial, savings, and cooperatives) and mortgage banks. Descriptions of the different business models are provided by Krahnen und Schmidt (2004) and Koetter (2013). In a nutshell, the former three types of banks are universal banks that take deposits and originate loans as their main activity. But they also conduct investment banking activities, such as underwriting and trading securities, provide advisory services, or sell insurance related services and products. Each pillar exhibits a two-tier structure with a few large, (inter)nationally active intermediaries and associated regional ones. Commercial banks are privately owned although only a few are stock market listed, mostly the largest institutions. Regional savings banks are owned by regional governments and own, in turn, their head institutions, the Landesbanken. Regional savings are de jure confined to stipulated local markets and focus on retail deposit taking and lending. Head institutions act as clearing house and gateways to international capital markets and investment banking services to their owners. Cooperative banks, in turn, are mutually owned by member-depositors. They pursue a de facto regional segmentation of banking markets and are the smallest universal banks. Like the savings banks' pillar, they feature two head institutions, which pursue activities roughly comparable to those conducted by the large commercial banks and the Landesbanken.

Finally, we include mortgage banks, which are specialized financial intermediaries that focus on the long-term maturity transformation by originating real estate mortgages. They also specialize on issuing covered bonds ("Pfandbrief"), which are often collateralized by sovereign bonds. The aggregate market share in terms of total assets of mortgage banks is around 8 percent (Koetter 2013).

We exclude affiliates of foreign banks operating in Germany because we do not observe their sovereign portfolios held by foreign parent banks. Special-purpose banks, such as automobile or development banks, are also omitted. In total, we sample 1,970 banks, which gauge for all practical purposes the population of German banks relevant to our study.

\subsection{Security holdings data}

The Securities Holdings Statistics of the Deutsche Bundesbank are a unique micro dataset providing detailed information on banks' investments in marketable securities (Amann et al. 2012). Each bank that is located in Germany reports its entire securities portfolio including sovereign bonds on a security-by-security basis. We focus on investments in sovereign bonds, defined as general government bonds rather than central government bonds only. We exclude public covered bonds from the sample. Covered bonds play a prominent role for the business model of mortgage banks, which are important issuers of these securities that are

\footnotetext{
${ }^{1}$ An alternative source of information on banks' foreign investments is the "External Position Report" of the Deutsche Bundesbank (Fiorentino et al 2010, Buch et al. 2011). This dataset contains information about the international assets of German banks and their foreign affiliates, but it does not identify important domestic (German) bond exposures, nor does it distinguish non-marketable loans to a country from sovereign bonds.
} 
collateralized by government securities in case of public covered bonds. However, their riskreturn trade-off depends on both the riskiness of the underlying sovereigns and the issuing bank. Most importantly, the data available to us precludes identification of the specific sovereign bonds pledged as collateral for a certain public covered bond.

The Securities Holdings Statistics data are available to us on a quarterly basis as of Q4:2005 until Q3:2013 and covers around 9,540 sovereign bonds (as of Q3:2013). Our sample period thus covers regular times prior to the Lehman failure as well as the Banking and European sovereign debt crisis periods thereafter.

We make two further sampling choices. First, we only consider banks' own securities holdings ("Depot-A-Geschäft"). Positions held on behalf of clients as well as the exposures of banks' foreign affiliates are excluded. Unfortunately, we cannot distinguish between holdings held-to-maturity and holdings available-for-sale, which have only been reported separately since early $2014 .^{2}$ The securities that banks report include all traded securities as well as repurchase agreements. For each security, we observe the ISIN number, currency, volume of investment, price, type of security, sector of the issuer, country, maturity, coupon type, frequency of coupon payments, and coupon payments. ${ }^{3}$

Second, we use sovereign bond holdings from OECD countries. These exposures dominate the sovereign bond portfolio of German banks, and these countries are fairly homogenous. A focus on OECD countries allows analyzing distinct developments in the eurozone in comparison to other OECD countries. ${ }^{4}$ Because we are interested in the macroeconomic features that affect banks' investments in certain sovereign bonds, we aggregate the data per country. For issuers like France, for instance, we have a total of 812 different securities at each point in time, which differ in terms of maturity and return. We aggregate these securities into a composite French sovereign bond. As a bond return measure we take the yield on the 10-year French sovereign bond. ${ }^{5}$

The data report notional and market values of securities. Notional values equal the nominal value of a security multiplied by the number of securities held. The market value is the product of the number of securities reported to Bundesbank and the price of the security as obtained from the Centralized Securities Database of the ESCB (Amann et al. 2012). Given

\footnotetext{
${ }^{2}$ However, a comparison of bond holdings according to either valuation for the available sovereign bond data since 2014 indicates an average market-to-book ratio across German banks on the order of 1.04. This ratio indicates therefore a rather robust measurement of sovereign debt exposures in our empirical analysis.

${ }^{3}$ For the sake of completeness, we include bonds with coupon as well as zero coupon bonds. Zero coupon bonds are counted at purchase price plus accrued interest and account for only $8 \%$ of total observations. The use of aggregate country-level data means that negative exposures are largely avoided. Also note that approximately $5 \%$ of all observations at the level of the individual security (ISIN) are short positions (as of Q3:2013), with large commercial banks $(20 \%)$ and Landesbanken $(11 \%)$ exhibiting the largest shares commensurate with their most active role in financial markets. At the aggregate country level, however, this share is negligible and only $0.7 \%$ of observations exhibit negative values (Q3:2013).

${ }^{4}$ Note that all securities denominated in foreign currency are either reported or converted at daily official Bundesbank exchange rates to Euros. Only $3.7 \%$ of sovereign bonds held by German banks are not denominated in Euroseuros as of Q3:2013.

${ }^{5}$ The average maturity in our sample is 11 years and thus fairly close to the 10 year benchmark yield.
} 
our interest in the relationship between sovereign bond holdings and bank risk, we focus on reported market values to capture possibly deteriorating bank profitability levels and increasing volatility.

A remaining challenge pertains to different accounting standards and the treatment of losses from security trading. Sovereign bonds held for trading or available-for-sale are evaluated at fair value. Therefore, any turmoil in sovereign debt markets associated with large price fluctuations will directly impact the level and the volatility of bank profits, and thereby also accounting-based measure of risk, such as the z-score. In contrast, sovereign bonds that are held-to-maturity are evaluated at amortized costs. As mentioned before, we do not observe the trading book and the banking book separately during the estimation sample period. Both categories are jointly reported as one variable until 2014. Our results on sovereign risk transmission to banks thus show the average effect for both accounting categories and should be higher for the (unobservable) subgroup of sovereign bonds, which are marked to market. Robustness tests yield, however, no sensitivity of regression results reported below for the choice of nominal versus market value of sovereign bonds. Also, market-based measures of bank risk provide similar findings, and since both valuations are reported separately (as of early 2014), they are correlated with more than $99 \%$. Therefore, we are confident that our analysis provides sufficiently robust indications on the nexus between sovereign debt and bank risk.

\subsection{Country-level macro data}

We complement the Securities Holdings Statistics with country-level information drawn from the Centralised Securities Database (CSDB), MarkIT, and the OECD. The country-level variables can be grouped into variables measuring market size, returns, and risk. We expect that banks will invest more in larger markets, in markets with higher expected returns, and in those exhibiting lower risk.

Table 1 shows descriptive statistics for country-level variables at the bank-country-quarter level of the analysis, distinguishing the selection and the outcome equation of the Heckman model. The left-hand panel contains 1,632,540 complete bank-country-quarter observations. The unconditional probability that bank $i$ holds bonds issued by country $j$ at time $q$ is around $5 \%$. The right-hand panel shows the sample with non-zero sovereign bond holdings only. These data comprise 83,698 bank-country-quarter observations, corroborating the potential self-selection of banks into holding sovereign debt. The average volume of sovereign bond holdings of an issuer by a bank in the regression sample is $€ 100$ million.

To measure market size, we use the log of a country's GDP. Data are in constant prices as of the year 2005 and are seasonally adjusted. Because we are explaining security holdings rather than flows, we also use the ratio of debt issued by the general government relative to GDP as an indicator of the depth of the sovereign bond market. 
To gauge expected returns and country risk we first include consumer price inflation. Higher inflation reduces real returns on outstanding government. Second, we specify bond yields to capture the compensation that the banks receive for holding risky government debt. Third, we include an indicator variable if a country participated in a support programme of the International Monetary Fund (IMF). These data are obtained from the homepage of the IMF and include Extended Fund Facilities, Extended Arrangements, and Stand-by-Arrangements. This indicator equals one from the start dates of IMF programmes. ${ }^{6}$ GDP, government debt and inflation data are all obtained from the OECD database in quarterly frequency. Bond yields are the average yield on a 10 year government bond as obtained from Markit.

Finally, there are several regulatory incentives for banks to hold sovereign debt in their portfolios. We include an indicator variable equal to one for member countries of the European Monetary Union (EMU) because prudential regulation in Europe favours banks' investments in sovereign debt issued by eurozone governments. More precisely, sovereign bonds denominated in the home currency need not be backed by equity capital under the Credit Risk Standardised Approach (CRSA) of the (current) regulatory framework. This favourable treatment of sovereign bonds will be maintained under the Basel III regime to be implemented into European law. 7 As an alternative to the Standardised Approach, banks might also use internal models to gauge the risk of their exposures and the necessary capital buffers (Internal Ratings Based Approach, IRBA). However, for sovereign bonds, an exemption allows IRBA banks to use the Standardized Approach for sovereign debt investments under certain circumstances ("permanent partial use"). Also, investments in sovereign bonds, that carry a zero risk weight, are exempt from large exposure rules.

\subsection{Bank-level supervisory data}

We use financial data reported to Deutsche Bundesbank to generate bank-specific control variables:

- Size: Because large banks were pivotal to absorb government bonds during the sovereign debt crisis (Becker and Ivashina 2014), we include the logarithm of total assets.

- Liquidity: Sovereign debt has an important impact upon the liquidity position of banks (Gennaioli et al. 2014). We measure liquidity through the ratio of cash and overnight interbank lending relative to total assets.

\footnotetext{
${ }^{6}$ These countries are Greece (Q2:2010), Hungary (Q2:2008), Ireland (Q4:2010), Mexico (Q2:2008), Poland (Q1:2013), and Portugal (Q2:2011). We also tested alternative country risk proxies, such as ratings (averaged over Moody's, Fitch, and Standard and Poor's) and CDS spreads. Results remained qualitatively unaffected and are available upon request.

7 See Brussels, 20 July 2011, COM(2011) 452 final, 2011/0202 (COD), Proposal for a Regulation of the European Parliament and of the Council on prudential requirements for credit institutions and investment firms, Article 109(4): "Exposures to Member States' central governments and central banks denominated and funded in the domestic currency of that central government and central bank shall be assigned a risk weight of $0 \%$."
} 
- Asset structure: Different degrees of retail versus financial market activities also characterize alternative bank business models (Boot and Ratnovski 2015). On the asset side of banks' balance sheets, we include the shares of customer loans (i.e. retail activities) and securities portfolios (i.e. wholesale activities) relative to total assets.

- Funding structure: Differences in banks' business models are also reflected in funding structures as wholesale funding structures have been more vulnerable during the crisis (Huang and Ratnovski 2011). To capture dufferent funding structures, we include core capital and retail deposits, both scaled by total assets. Also, we include securitized liabilities relative to total assets as a proxy for the need for collateral. These liabilities may contain both, funding obtained at the secured interbank market as well as from central bank operations.

- Profitability: We include bank profitability as measured by return on equity and efficiency as captured by banks' cost-to-income ratios. The impact on bank risk is ambiguous. On the one hand, more profitable and more efficient banks should tend to have higher capital buffers and be able to buffer shocks. On the other hand, higher profitability may also imply that banks search for yield and are willing to take on higher risks.

- Income structure: Finally, we account for difference in the income structure across banks by including fee over interest income.

Fixed effects for each banking group capture remaining systematic differences in banks' business models.

Table 2 shows these data for, both, the selection equation (left-hand panel) and for the outcome equations (right-hand panel). Table 3 shows these data for bank risk regressions. Total assets and the funding structure are observed quarterly. Other bank variables are available annually, and we interpolate quarterly data in the sovereign bond holdings regressions.

\subsection{Descriptive Statistics}

An important upshot of the comprehensive data on the securities holdings of German banks is that not all German banks hold sovereign debt. At the end of our sample, in Q3:2013, for example, about a quarter of all German banks held no sovereign bonds at all. Figure 1 shows that, over time, around $10 \%$ of all German banks are never active in sovereign bond markets whereas around a quarter are always active. The never-participating banks are primarily cooperative banks, but never mortgage banks. Non-participating commercial banks tend to be better capitalized, much smaller, and more engaged in interbank lending compared to participating banks. These features may explain a reduced need for sovereign bonds. The remaining banks change in and out of sovereign bond markets and Figure 1 clearly illustrates 
the retreat from these markets after the demise of Lehman and gradually increasing participation after Q4:2009.

Figure 2 shows the evolution of the participation rate in sovereign bonds markets per banking group over time. Differences in banks' business models imply a different need for sovereign bonds across banking groups. Despite the variation in the level of participation rates, there is a common trend across banking groups towards a higher participation rate (Figure 2).

Table 4 provides a snapshot on the importance of the security portfolio in German banks' balance sheets at the end of our sample (Q3:2013). On average, German banks held 18\% of their total assets in securities, ranging from $11 \%$ for commercial banks to $27 \%$ for mortgage banks in Q3:2013 (Column 4). About 5\% of total assets were invested in sovereign bonds, ranging from 3.5\% for commercial banks to $13 \%$ for mortgage banks in Q3:2013 (Table 4, Column 5). This heterogeneity between banking groups has been more pronounced before the financial crisis. Since 2008, savings and cooperative banks increased their investments in sovereign bonds (Figure 3). Starting from higher levels, mortgage banks decreased their sovereign exposures from 2006 onwards.

Figure 3 depicts the decomposition of the sovereign bond portfolio over time and per banking group (as a percentage share of total assets). Across banking groups, portfolios were heavily concentrated towards Germany and the eurozone. ${ }^{8}$ Also, changes in the size of the sovereign portfolio were primarily driven by adjustments in the German sovereign bond holdings. Commercial banks withdrew from the eurozone periphery countries (Greece, Italy, Ireland, Portugal and Spain) since the beginning of 2010 and reallocated their assets towards Germany and other core countries. Mortgage banks held an exceptionally high share of bonds issued by European periphery countries, namely $41 \%$ of their overall sovereign portfolio (Q3:2013). Also, they increased their investment in other eurozone countries and in OECD countries outside the eurozone since the outbreak of the European sovereign debt crisis. Hence, mortgage banks hold the most diversified sovereign bond portfolios compared to the other banking groups.

In terms of the number of countries in which the average bank invests, Figure 5 confirms that mortgage banks are quite diversified. Whereas mortgage banks held sovereign bonds of 8 countries on average in Q3:2013, the other banking groups held exposures towards 2 (cooperatives) to 3 countries (commercial banks) only. ${ }^{9}$ However, the five largest (commercial) banks held sovereign bonds in 25 countries on average. Thus, sheer size of countries seems to be an important determinant for diversification strategies.

\footnotetext{
${ }^{8}$ Although portfolios are dominated by German bonds, our main results are unaffected when excluding German bonds from the regressions.

${ }^{9}$ If we exclude banks that hold no sovereign debt at all, the average number of countries rises by one.
} 
Figure 4 illustrates the evolution of aggregate German bank exposures to selected countries over time. While German bonds have always dominated the portfolio, this pattern has been reinforced in recent years. Especially after the fall of Lehman in Q3:2008, we observe a steep increase in German bond holdings and, to a lesser extent, in French bonds. This increase is accompanied by continuously declining positions vis-à-vis distressed eurozone peripheral countries, which was amplified after the outbreak of the sovereign debt crisis in the second quarter of 2010. Thus, the data strongly suggest a home bias pattern to holding sovereign bonds, which is consistent with the "flight to safety" effect documented by Hildebrand et al. (2012).

In sum, the descriptive statistics reveal a couple of interesting patterns in the data. First, a significant fraction of German banks do not invest in sovereign bonds at all. Second, with 5\% of the total, sovereign bonds account for a relatively small share of banks' total assets (Q3:2013). Third, sovereign bond portfolios in particular for smaller banks are not very diversified, and a high share is held in eurozone bonds.

\section{Determinants of banks' sovereign bond holdings}

We combine sovereign portfolio data of all German banks with country-level and bank-level information to answer two questions. First, what are the determinants of banks' investments in sovereign bonds? Because not all German banks hold sovereign bonds, we account for selection bias with a Heckman-type model. Second, what is the impact of sovereign bond holdings on bank risk? We use predicted values of sovereign bond holdings to answer this question in section 4 .

\subsection{Estimation strategy}

We model the banks' decisions whether to invest in government bonds and which volume of bonds to hold through a Heckman (1979) selection model. First, we model whether a bank $i$ holds sovereign bonds of country $j$ in period $q$ (extensive margin, EXP). Second, we explain the size of exposures in terms of the Euro volume of sovereign bonds (intensive margin, $S O V)$. Accordingly, we specify a selection equation (1) and an outcome equation (2):

$$
\begin{aligned}
& \operatorname{Pr}\left(E X P_{i j q}=1\right)=\Phi\left(\alpha_{1 g}+\alpha_{1 j}+\alpha_{1 q}+\beta_{11} X_{i q-4}^{\prime}+\beta_{12} X_{j q}^{\prime}\right) \\
& \operatorname{Sov}_{i j q}=\alpha_{2 i}+\alpha_{2 j}+\alpha_{2 q}+\beta_{21} X_{i q-4}^{\prime}+\beta_{22} X_{j q}^{\prime}+\eta I M R+\varepsilon_{i j q}
\end{aligned}
$$

In the selection equation (1), EXP $P_{i j q}$ is an indicator variable equal to 1 if bank $i$ (1,970 banks) holds sovereign bonds of a specific country $j$ (29 countries) in time period $q$ (quarterly data from Q4:2005 to Q3:2013) and 0 otherwise. The estimation sample comprises 1,632,540 bank-quarter-country observations. $\Phi($.$) is the standard normal distribution function, X_{i q-4}$ are bank-specific, and $X_{j q}$ are country-specific control variables. We include fixed effects for banking groups, quarter, and country $\left(\alpha_{1 g}, \alpha_{1 j}, \alpha_{1 t}\right)$ in equation (1). In the outcome equation 
(2), we include fixed effects for bank, quarter, and country. We specify fixed effects for banking group instead of banks in the selection equation (1) to avoid the incidental parameters problem in Probit estimations. Bank-specific variables are lagged by four quarters to alleviate simultaneity concerns. Country-specific variables enter the equations contemporaneously.

Identification would ideally hinge on a variable that represents a valid exclusion restriction, i.e. variables $W$ that correlate only with the likelihood of bond holdings in a given country in a given quarter but not the volume of such an exposure. As no quantitative restrictions on specific sovereign bond exposures prevail and as existing regulations may affect boths the extensive and the intensive margin, we cannot specify such variables $W$. Therefore, the model is identified based on functional form. Based on the predicted likelihood of observing an exposure of bank $i$ in country $j$ at time $q$, we then calculate the inverse Mills ratio $(I M R)$. Together with the same bank-specific and country-specific control variables $\left(X_{i q}\right.$ and $X_{j q}$ ) and the fixed effects, the IMR is specified in the outcome equation (2) to explain differences across banks' observed sovereign debt exposure levels (SOV). The coefficient $\eta$ indicates if significant self-selection bias of banks into holding sovereign bonds prevails.

To specify equations (1) and (2), we combine three data sources: the Securities Holdings Statistics of the Deutsche Bundesbank, bank-level data from the supervisory department of the Deutsche Bundesbank, and destination country characteristics from public data sources such as MarkIT, the OECD, and the Centralised Securities Database (CSDB). Detailed data definitions are given in the Appendix.

\subsection{Baseline regression results}

Column (1) in Table 5 shows the determinants of banks' sovereign bond holdings, the intensive margin. Column (2) shows the results for the selection equation from the Heckman model. Column (3) provides marginal effects for the extensive margin. Overall, this model explains sovereign bond holdings of German banks fairly well. The adjusted $R^{2}$ of the outcome equation in Table 4 equals 0.75 . Even without bank, time, and country fixed effects (unreported), the adjusted $R^{2}$ still amounts to 0.55 .

Consider first the importance to account explicitly for systematic selection by banks whether to hold bonds issued by a certain country in a given quarter. The inverse Mills ratio in column (1) is significant at the $10 \%$ level. Therefore, the choice whether to invest in a particular market also affects the decision on the volume of investment. Our results based on this comprehensive sample comprising all German banks underpin the importance to analyse not only selected groups of systemically relevant banks, such as in the EBA stress tests, but to account for the non-random determinants of sovereign holdings when assessing the implications for bank risk. 


\subsubsection{Country-level determinants}

For the entire sample, virtually all covariates exhibit statistically significant impact on sovereign bond holdings, both for the extensive and the intensive margin. The effect of larger markets is in line with expectations. Both, the likelihood to hold government bonds from a certain country and the volume of such exposures correlate positively with country size and with debt-to-GDP ratios. Given that higher debt-to-GDP ratios may also affect the underlying degree of sovereign risk, we will test below whether sensitivity to such risks has changed during the crisis.

With respect to macro covariates capturing expected return and risk, we find, perhaps contrary to expectations, that banks hold more government debt from countries with high inflation and low bond yields. Hence, we do not see a "search for yield" of German banks in sovereign bond markets. Instead, the increasing sovereign risk that came with higher bond yields seems to have dominated the return effect. Due to multicollinearity we are not able to jointly include bond returns and CDS spreads in the regression. As a robustness check, we have replace returns with sovereign CDS spreads or ratings, and the negative coefficient on risk remained unchanged (results not reported).

Banks withdraw from countries that are covered by an IMF program. In unreported tests, we check whether banks hold relevant exposures to countries participating in IMF programs to begin with. German banks held $6-13 \%$ of total sovereign exposure towards debt of IMF program countries prior to the start of the average program, especially mortgage banks. In the quarter following the announcement of an IMF program, all banking groups reduce their exposures. Mortgage banks exhibit the most significant decline, namely by $22 \%$ of their exposure prior to the announcement.

In addition to these macro variables, we also find a positive eurozone effect. This could reflect the absence of exchange rate risk, the preferential regulatory treatment of sovereign bonds from these countries, or eligibility for ECB refinancing. Below, we will investigate in more detail differences in the effects of macro covariates across different types of issuer countries.

To interpret the size of the parameters in the equation for the extensive margin, we calculate average marginal effects from the Probit model. The economic significances reflected by marginal effects reported in column (3) of Table 5 indicate that inflation, country size, and membership in the eurozone increase the probability of sovereign bond holdings the most.

\subsubsection{Bank-level determinants}

Correlations of proxies for business models of German banks and banks' investments into government bonds are shown in the lower panel of Table 5. Results for the selection equation show that larger, less well capitalized banks, banks larger securities portfolio, and banks with lower customer loan shares are likely to hold more government debt. These results are in line 
with Acharya and Steffen (2015), who find that larger banks and banks with lower capital ratios invest more in sovereign bonds. The negative impact of the capital ratio could reflect a risk effect: banks with low capital buffers should be inclined to invest more in presumably safe assets.

Banks with a larger share of liquid assets (i.e. cash and overnight assets) also invest more in sovereign bonds (Gennaioli et al. 2014). This indicates that sovereign bonds are not used as a substitute for other liquid assets but rather as an additional source of liquidity. The share of retail deposits does not affect the likelihood to invest in sovereign bonds significantly, but it correlates positively with government bond volumes held. Furthermore, sovereign bonds are an important source of collateral to obtain interbank funding, and thus sovereign bonds play a more important role for banks with a wholesale funding structure. The negative impact of the customer loan share, paired with the positive effect of securitized funding, suggests that banks with a wholesale business model invest more in sovereign bonds.

\subsection{Are determinants of bond holdings stable over time?}

We have so far assumed that the determinants of banks' investments into sovereign bonds have remained unchanged over time. Yet, during the crisis, perceptions of sovereign default have changed markedly, low interest rates induced a search for yield, and banks needed collateral to cushion liquidity shocks. In order to analyse whether the determinants of banks' sovereign exposure have changed over time, Table 6 presents result for three separate time period: the pre-Lehman period (Q4:2005-Q2:2008), the period from the Lehman default until the outbreak of the Eurozone sovereign crisis (Q3:2008-Q1:2010), and the period of the sovereign crisis (Q2:2010-Q3:2013). ${ }^{10}$

Table 5 shows that, macroeconomic factors had virtually no impact on banks' sovereign bond investments prior to the financial crisis of 2008. Results reported in Table 5 for the full sample are thus largely driven by the post-Lehman periods which provide evidence of active restructuring of banks' sovereign debt portfolios. This result is in line with previous literature on the determinants of sovereign bond spreads for the eurozone countries, which attributes little explanatory power to macroeconomic factors before the crisis but considerable responses during the crisis (de Grauwe and Ji 2012).

After the outbreak of the sovereign debt crisis, the impact of macro factors has changed in three significant ways.

First, while the impact of high levels of debt had a positive impact on banks' investments, perhaps as a reflection of deeper markets, the impact turns significantly negative after the outbreak of the sovereign crisis. In line with expectations, high debt levels seem to have taken as a signal of higher risk since Q2:2010. Below, we will show that (predicted) holdings of

\footnotetext{
${ }^{10}$ We also split the sample in Q3:2007 after the first strains on the money market. Results of unreported regressions are similar.
} 
sovereign debt in risky categories correlate positively with bank risk since the outbreak of the sovereign crisis.

Second, the positive effect of inflation on bond holdings reported for the full sample is driven by the sovereign crisis period. Until the outbreak of the sovereign crisis, the impact of the inflation rate is negative.

Third, high sovereign yields lured banks after Lehman, potentially due to regulatory preferential treatment paired with a search for yield motive (Acharya and Steffen 2015). Since Q2:2010, banks avoided high-yield government bonds potentially due to adapted expectations about sovereign default probabilities.

In sum, our results suggest that banks have responded quite differently to macroeconomic factors before and after the the collapse of Lehman Brothers. Before that event, banks did not differentiate much between sovereign debt on grounds of macro fundamentals. These factors became relevant afterwards Lehman, and much of the adjustment is in line with expectations as banks became more sensitive to underlying risk factors. Bank-level determinants of banks' investments into sovereign bonds, in contrast, have remained much more stable over time.

\subsection{Do banks' business models matter?}

Next, we investigate differences of macro and bank-level effects on sovereign debt holdings within different banking groups to account more explicitly for the heterogeneous business models which may entail alternative reasons to hold government securities. Against the backdrop of the previous results, we report here only estimates for the outcome equation and separate banking group subsamples further into pre and post sovereign crisis in Table 7.

All in all, our results from pooled regressions are not primarily driven by differences in business models between banking groups but mirror also differences in business models within banking groups. Regarding the effect of macroeconomic factors, three main results are worthwhile to highlight. First, across all four banking groups the two variables gauging real yields of sovereign debt convey opposing signals before and after Q2:2010. Higher yields offered by low inflation countries correlated with larger holdings of debt before the sovereign crisis. These effects reversed after the outbreak of the crisis, which confirms the previous indication that banks were seeking yields prior to the turmoil in the eurozone, but reconsidered the importance of real returns after the outbreak of the sovereign crisis.

Second, specialized mortgage banks with the largest sovereign bond exposures are not affected by any of the macro factors except yields and inflation. Contrary to the universal banks, the volume of government debt held by mortgage banks depends mostly on bankspecific factors, such as the need for collateral associated with covered bond securitization.

Third, specific banking groups drive the results for certain macro factor effects reported at the aggregate level in Table 6 . The positive correlation with country size prior to the sovereign crisis depends on the largest group of small, retail-oriented cooperative banks. The 
changing effect of IMF programs is due to the savings and cooperative banking sector subsamples, indicating a changing interpretation of an IMF mission as insurance after the outbreak of the crisis rather than an indication of increased riskiness. The absence of an aggregate eurozone effect in Table 6 camouflages a strong re-shifting of cooperative banks' sovereign portfolios into eurozone debt.

With respect to bank-level variables, results per banking group highlight that across the alternative business models and motives to hold sovereign debt, two factors exert identical effects on sovereign debt holdings: larger banks with larger shares of security portfolios hold more government debt. Other variables of banks' financial profiles indicate heterogeneous effects between banking groups, of which we highlight three.

First, proxies of retail-orientated business models, such as the customer loan share, the importance of the security portfolio, or the share of fee income, indicate smaller sovereign bond holdings for the aggregate sample (see Table 5). The results in Table 7 detail this finding. Savings and cooperative banks, which are the most retail-based banks in Germany, indeed hold fewer government bonds if they hold also more customer loans whereas commercial and mortgage banks exhibit the opposite relationship.

Second, the aggregate results suggest that business models relying more on wholesale and capital market funding exhibit mixed results: both retail deposit shares and securitized funding shares correlate positively with government bond holdings. The split according to banking groups clarifies that retail-based funding strategies pursued by savings and cooperative banks correlate significantly negative with bond holdings whereas the effect for commercial banks changes direction before and after the outbreak of sovereign turmoil. The specialized mortgage banks and their predominant role in the covered bond segment do not drive the positive effect of securitization activity on bond holdings. In fact, privately owned universal banks, i.e. commercial and cooperative banks, drive this result, in particular after the outbreak of the sovereign debt crisis.

Third, the aggregate results suggest that more risk-inclined business models absorbed more sovereign debt, possibly from the more risky periphery in the eurozone in a quest for yield. The positive effects estimated for larger returns on equity and lower capital ratios are also put into perspective by the sample split according to banking groups. Return on equity is only significantly positively related to bond holdings for mortgage banks, in particular prior to the crisis. Commercial and cooperatives exhibit positive, yet insignificant correlations. More profitable savings bank hold less government bonds. Return considerations therefore may be particularly relevant for the specialized business model of mortgage banks with more limited investment opportunities compared to the universal banking sector. Capitalization, in turn, indicates in line with Acharya and Steffen (2015) more clearly that less capitalized banks also tend to hold sovereign debt, potentially because of favourable regulatory treatment. This effect reverses only for commercial banks after the outbreak of the crisis. 
Among commercial and mortgage banks, we find a change in significance and in the sign of the variables with the outbreak of the sovereign crisis. Savings and cooperative banks, in turn, exhibit the fewest changes regarding which variables correlate how with their sovereign bond holdings. This result may indicate that the turmoil of the sovereign debt crisis affected the business models of the former two banking groups the most, inducing them to reconsider the information content of macro variables for holding government bonds since Q2:2010.

In sum, banks that pursue more retail oriented investment strategies hold fewer bonds whereas banks with a stronger focus on capital markets for funding and investment purposes use government bonds more extensively. But after the outbreak of the sovereign crisis, more capital market affine commercial banks and specialized mortgage banks consider different factors when choosing government debt compared to pre-crisis times, which may indicate a generally more intense need for these business models to adapt to the sovereign crisis shock.

\subsection{Are determinants of sovereign holdings stable across countries?}

The changes in the effects of macroeconomic variables on banks' investments into sovereign bonds suggest that different countries might be driving our results. The re-pricing of sovereign risk has been particularly pronounced in the Eurozone. Therefore, we next estimate the selection and the outcome equations separately for non-eurozone bonds, eurozone bonds, eurozone crisis countries (Greece, Italy, Ireland, Portugal, and Spain), and for German bonds. Table 8 reports only results for the outcome equations and for the full sample.

Regarding the effect of macro covariates in the upper panel, the effects mimic by and large those for the aggregate sample findings in Table 5. Two important differences are that higher yields within the sample of periphery country debt appear to signal excessive riskiness and reduce bond holdings whereas IMF interventions only reduce government bond holdings of countries that are not a eurozone member.

Regarding bank-level variables, higher bank liquidity is associated with reduced eurozone periphery bond holdings, but larger German bond holdings. This result corroborates a flight to safety argument as in Hildebrand et al. (2012). The retail deposit share and the customer loan share suggest that banks with a larger local funding and investment base reshuffled their sovereign exposures towards German bonds. To the extent that in particular savings and cooperative banks experienced a substantial inflow of retail funds, possibly as a result of a confidence shock among small, uninformed household savers, the demand for German bonds is consistent with a search for safe assets.

Finally, consider the effects of different crisis indicator variables in the bottom panel of Panel 7, which shows that only the impact of sovereign debt crisis differs between types of sovereign bonds. In response to the first money market tensions in August 2007, government debt holdings were reduced across the board. But German banks increased their exposures after the collapse of Lehman again, although with a first indication of home bias as the effect on non-eurozone is insignificant. The flight into eurozone bonds after Lehman exceeded the 
initial withdrawal from these bonds after the first money market strains in August 2007. With the outbreak of the sovereign debt crisis in 2010, they actively withdrew from non-eurozone countries. For eurozone bonds, the flight to Germany predominates whereas we cannot detect a statistically significant effect on periphery debt.

\subsection{Additional robustness tests}

We performed various robustness checks and the following results are not reported here but are available upon request. Our main results regarding the impact of country and bank variables on both the likelihood and the volume of held sovereign bonds are overall robust.

First, we excluded German bonds, which account for a very large share in security portfolios, to ensure that the effects documented are not solely a flight-to-safety phenomenon. Second, we relaxed the assumption that banks react to macroeconomic changes immediately. Like bank-specific covariates, we also lag the macro country variables by four quarters. Third, we checked the importance of outliers and winsorised all covariates at the $1 \%$ and $99 \%$ quantile. Fourth, we excluded the observations in Q4:2005 to Q1:2007 to ensure that results were not influenced by potential data issues in the starting phase of the Securities Holdings Statistics in 2006. Fifth, we used notional instead of market values of sovereign bond holdings to address concerns that prices do not reflect the accounting values that banks use and that we estimate pure price instead of quantity effects in sovereign bond holdings. Sixth, we distinguished the sovereign bond holdings per country for three maturity bands: Bonds with a maturity of less than 5 years; with a maturity of between 5 and 15 years; and bonds with a maturity of more than 15 years. Results are qualitatively very similar between short, intermediate, and long-term bonds, except for the coefficient on bond yields that turns negative for longer maturities in the outcome equation.

\section{Do sovereign debt exposures affect bank risk?}

\subsection{Estimation strategy}

Our second main research question is how banks' sovereign bond holdings affect bank risk. To this end, we estimate a fixed effects model for a panel of 1,490 banks for which we obtained micro-prudential supervisory financial accounts data, which is available annually for the period 2005 until 2012. Only banks that hold sovereign bonds are included. We aggregate predicted sovereign positions within three risk categories, thereby eliminating the country dimension from our data. Our baseline measure of bank risk is the $z_{\text {score }}$, which is defined in the data appendix, and we estimate:

$$
\text { zscore }_{i t}=\alpha_{i}+\alpha_{t}+\beta_{1} X_{i t-1}+\beta_{2} S \hat{O} V_{i t-1}+\varepsilon_{i t},
$$

where $a_{i}$ and $a_{t}$ are bank- and year-fixed effects, $X_{i t-1}$ is a vector of bank-level controls lagged by one year to avoid simultaneous correlation by construction, and $S \hat{O} V_{i t-1}$ is a vector 
of predicted values of banks' sovereign bond exposures. The parameter of interest is $\beta_{2}$, which indicates whether and to what extent sovereign debt holdings influence bank risk. We use clustered standard errors at the bank level.

We use predicted rather than observed sovereign bond holdings for two main reasons. First, conditional sovereign holdings account for the selection bias because banks systematically choose whether and which bonds to hold. By using estimated coefficients that are estimated conditional on the inclusion of the inverse Mill's ratio, these predictions properly account for banks' different reasons to hold a certain bond in a certain quarter. Because we also include bank-specific controls $X_{i t}$ in the estimation of the selection and the outcome equation, we gauge possibly different risk preferences that prevail across business models in German banking. Predictions are obtained from the estimates for the intensive margin reported in Table 5, which we aggregate by bank, quarter, and risk category.

We construct three risk categories: all bond holdings of sovereigns rated AAA represent low risk sovereign bond holdings. Bonds rated AA or A are intermediate risk holdings, and sovereigns rated $\mathrm{BBB}$ or worse fall into the high risk category. The rating is an average rating of Moody's, Standard and Poor's and Fitch. We then take end-of-year values for the sovereign bond holdings. Table 13 tabulates the sovereigns by risk category. ${ }^{11}$

Second, using predicted sovereign bond holdings mitigates concerns arising from possible reverse causality. The risk appetite of banks, as for instance born out by different business models, is likely to affect their holdings of sovereign bonds. Sovereign exposures, in turn, are correlated with observable risk traits that are part of the z-score because shocks like those in early 2010 will affect return levels and volatility, for example. The use of predicted, aggregated exposures is thus in the spirit of an instrumental variable approach, with country specific macro factors $X_{j t}$ being excluded in the second stage regressions on bank risk. In both stages, when explaining sovereign debt holdings and bank risk, we use classical CAMEL covariates to control for risk (appetite) of a bank. Because the dimensions of the selection model (bank-country-quarter) differ from those of the bank risk sample (bank-year), we cannot apply the conventional tests for the adequacy of "instruments". But we conduct some plausibility tests.

From a statistical perspective, we need to validate the ability of macro-covariates to properly gauge the selection bias otherwise embedded in bank-specific CAMEL covariates aiming to gauge risk differences across banks. Country covariates predict the intensive margin SOV very accurately and according F-tests for joint insignificance are rejected at the $1 \%$

\footnotetext{
${ }^{11}$ Note that this approach implies that we "migrate" some countries across categories over time. As we observe stocks of outstanding sovereign debt rather than flows, for some banks holdings high-risk debt might thus be less of a choice but instead the result of a re-classification of some countries' debt. Whereas our approach to use the share of sovereign bonds relative to total assets mitigates such concerns considerably, we draw no inference on causation but rather document correlation between predicted sovereign bond portfolio differences across banks and cross-sectional differences in observable risk proxies across these banks.
} 
significance level. A regression with country covariates only still yields a high adjusted $R^{2}$ of 0.341. At the same time, macro covariates should be uncorrelated with realisations of bank risk, that is country-specific factors should be orthogonal to the individual German bank. This seems plausible, given that even banks with large foreign exposures only hold small fractions of individual issuer countries debt. Therefore, a shock in one particular issuer country should be fairly uncorrelated with banks' realizations of risk on average. To test this, we use each banks bond portfolio share towards issuer country $j$ in quarter $q$ to generate exposureweighted macro covariates per bank and year. With the exception of IMF measures, all of these variables are not significantly correlated with the z-score, our measure of risk. Correlations are weakly significant at the $10 \%$-level when using observed portfolio rather than predicted portfolio shares, but very small regarding magnitudes and, as argued above, possibly contaminated with neglected selection bias. Therefore, we continue to use predicted sovereign bond shares in the three risk-categories to analyse the relationship with bank risk.

\subsection{Measuring bank risk}

We measure bank risk using the banks' $z$-score (Laeven and Levine 2009), which is defined as the return on assets plus equity over assets, divided by the standard deviation of return on assets:

$$
z=\frac{(E / A+R o A)}{\sigma_{R o A}}
$$

where $E / A$ is the capital-asset ratio, $R o A$ denotes return on assets, and $\sigma_{R o A}$ denotes the standard deviation of $R o A$. A higher $z$-score reflects a higher distance to default and thus lower risk.

To obtain a bank-time specific measure for volatility of $R o A$, we regress $R o A$ on bank and time fixed effects. The residuals of this regression give the volatility of $R o A$ of bank $i$ in year $t$ that cannot be explained by bank or time common effects. The residuals are winsorized and taken in absolute terms as measure for $\sigma_{R o A}$. This methodology is in the spirit of Loutskina and Strahan (2015) who applied it to house price changes. As a robustness check, the standard deviation of $R o A$ is calculated using a rolling window of seven years. Results for our coefficients of interest remain similar. z-scores measure the extent to which bank equity is sufficient to cover losses. We winsorise the $z$-scores at the $0.1 \%$ level to account for outliers.

Literature uses numerous accounting-based measures, such as non-performing loans, the volatility of bank-level reserves, profits (Beck 2008) or market-based measures, such as bank CDS. The former are either subject to statistical breaks (non-performing loans) or exhibit little to no time-series variation. The latter are available for the small number of listed German banks. The use of $z$-scores as a measure of risk has the advantage that it is based on prudential supervisory data and therefore available for all banks, listed as well as non-listed ones. An important disadvantage is the backward looking nature of this measure, which is typical for 
accounting-based risk measures. Another limitation concerns the failure of prudential data to fully gauge market valuation effects as the data in our sample period is based on hold-tomaturity portfolios. Therefore, we specify in addition two alternative measures of risk.

First, we specify the log of Credit Default Swap (CDS) spreads of each bank as a marketbased measure of risk that captures expected default risk of banks. CDS-spreads are considered a key indicator of financial sector resilience, which render them especially useful to our ends despite their sparse availability for only 24 German banks. Second, we specify an indicator equal to 1 if a bank was ranked in the top decile of distribution of non-performing loans (NPL) relative to total loans in a given year. ${ }^{12}$ We choose such a discrete indicator instead of continuously measured NPL shares because the definition of NPL changed two times since 1995, giving rise to statistical breaks (Koetter 2013). This approach ensures that we measure the relative risk of a bank relative to the system as a whole irrespective of changing NPL definitions over time.

Table 3 and 9 show descriptive statistics of the $z$-score variable, CDS spreads, the NPL indicator, and bank-specific covariates for the estimation sample. Given the definition of $z$ scores, we do not specify capitalisation and profitability as explanatory variables $X_{i t}$. Sovereign bond exposures are scaled by total assets of banks to capture the relative exposure towards sovereign risk. This sample comprises 6,907 bank-year observations and 1,490 banks, and summary statistics are very much in line with the bank-country-quarter sample shown in Table 2.

Our main measure of bank risk, the $z$-score, varies across banking groups and over time (Table 9, Panel a). Commercial banks and mortgage banks are, on average, the most risky banking group. However, the standard deviation and thus the heterogeneity of our risk indicator is also highest within the group of commercial banks. Savings and cooperative banks are less risky and much more homogenous regarding their risk profile. The $z$-score was lowest in 2011, signalling a high level of bank risk. The outbreak of the European debt crisis in 2010 took one year to show up in higher bank risk, as measured by the z-score. This might be related to accounting treatment of sovereign bonds at the time, which initially prevented realization of losses. In 2011 mortgage banks together with savings banks (incl. Landesbanken) and commercial banks exhibited the lowest z-score. In 2008 instead, another local minimum, commercial banks and mortgage banks were the most affected. Overall, our alternative risk measures, the NPL indicator and CDS spreads confirm these trends (see Table 9, panel $\mathrm{b}$ and $\mathrm{c}$ ). Relative to the other banking groups, mortgage banks exhibited a riskier loan portfolio in 2008 and 2011, as they were more often in the highest decile of NPL distribution in these years. CDS spreads increased steadily from 2005 until 2012, but started to decline in 2013 (not reported). Between banking groups, there is considerable variation.

\footnotetext{
12 Note that we define deciles on the basis of the entire population of banks, i.e. including those without sovereign exposures or missing data that precluded certain observations from the estimation sample.
} 
Mortgage banks exhibit the highest risks as perceived by markets in 2009 and commercial banks in the years of the sovereign debt crisis.

\subsection{Baseline estimation results}

Table 10 presents the baseline results for the risk equation using the (log) $z$-score as the dependent variable. The explanatory power for the aggregate sample is reasonable, exhibiting an $R^{2}$ of around $15 \%$. After controlling for bank and time fixed effects, only a few bankspecific covariates remain significant. Larger banks also tend to be more risky. However, the effect is economically small. An increase of total assets by $1 \%$ increases $z$-scores by $0.08 \%$. Besides size, we find only weak indications that banks holding more liquid assets, measured as cash relative to total assets, and with a larger reliance on wholesale funding in financial markets are also less stable.

The main variables of interest are the predicted volumes of sovereign bonds per risk category relative to total assets. For the entire sample period, we find no evidence of a statically significant relationship. But when we separate the sample into periods before and after the sovereign debt crisis, three important qualifications are noteworthy.

First, our model explains little of the variation in bank risk before the onset of the sovereign debt crisis, and the explanatory power increases to an adjusted $R^{2}$ of 0.16 only since then. In contrast, we explain only very little variation in $z$-scores prior to 2010. In either subsample fixed effects for banks and years gauge most of the variation in $z$-scores. Banklevel covariates explain little of the variation in bank risk before the sovereign crisis.

Second, predicted holdings of high-risk bonds have been associated with higher bank risk since 2010. One reason for this could be that valuation changes require some time until they materialize on banks' balance sheets. Intuitively, losses on sovereign bond portfolios did not affect banks immediately, possibly in part because of the preferential treatment of sovereign debt in central bank operations and capital regulation.

Third, low-risk bonds reduced bank risk significantly in both subsamples, an effect that we cannot estimate with sufficient precision in the full sample. However, compared to the effect due to an increase in the share of high-risk bonds, predicted low-risk bond holding effects are of a very small magnitude. In contrast, an increase in the predicted share of high-risk sovereign bonds of total bank assets by $1 \%$ increased the $z$-score by $0.8 \%$. This effect is not particularly large economically, but it is the only bank-specific covariate that remains significant after including fixed effects for bank and time fixed effects.

\subsection{Is it the business model? Results per banking group}

So far, we have found little evidence that bank-level characteristics affect bank risk, and the exposure to sovereign risk has had effects during the sovereign crisis period only. Mext, we ask whether different business models of banks affect these results by investigating the banksovereign risk nexus for each banking group separately. Table 11 shows the result. Due to 
small sample size, mortgage banks are omitted. Three important qualifications compared to the full sample are noteworthy.

First, for full sample we can explain decent shares of the variation in $z$-scores as confirmed by adjusted $R^{2}$ for each of the three banking groups ranging between $14 \%$ for commercial banks to $22 \%$ for savings banks. The risk of commercial banks is explained quite well in the two subsamples before and after the outbreak of the sovereign crisis in 2010, which is not true for cooperative and savings banks. Differences in risk across savings banks are, in particulary hardly explained by our model.

Second, the group of commercial banks drives the aggregate results. Prior to 2010, a larger asset share of low-risk sovereign bonds lowered the risk of commercial banks, which is consistent with the notion that safe government bonds serve as a liquidity buffer. After 2010, a larger share of intermediate-risk and especially high-risk government debt has a statistically and economically significant impact on the risk of commercial banks. Sovereign exposures have no significant impact on the risk of cooperative and savings banks, in contrast.

Third, estimated coefficients for bank-specific covariates in Table 11 confirm that, besides fixed effects for banks and years, only little is left in the variation of $z$-scores across banks to explain. The baseline result that larger banks tend to be more risky is driven by the group of commercial banks. The result that higher securitized funding correlates with bank risk, in turn, is driven by cooperative banks. Whereas we also estimate a negative coefficient for the share of securitised liabilities to total assets in the subsample of commercial banks, this effect is not statistically significant.

We performed various robustness tests, such as alternative aggregation methods for the sovereign bond holdings. Instead of taking the end-of-year values of a bank's sovereign holdings we took the mean holdings in each year. We also used observed (instead of predicted) sovereign bond holdings as a robustness test against the reliance on predictions. We also winsorised all explanatory variables. Overall, these changes did not the overall results.

\subsection{Market- and credit-based measures of risk}

One explanation for the absence of significance in covariates may be the limitations associated with the $z$-score as a measure of bank risk in this sample of German, mostly unlisted, small, and locally active banks. Therefore, we additionally changed the measures of risk entirely and show the results in Table 12.

First, we show in the left-hand panel parsimonious regressions explaining the log of bank CDS spreads. ${ }^{13}$ This sample is much smaller because CDS are available for only 24 German banks. But they have the advantage of gauging also market expectations and are thus a more

\footnotetext{
13 As data on CDS spreads are available more readily, we were able to extend the time period in these regressions until Q4:2013.
} 
forward looking measure of risk compared to the $z$-score. The effect of predicted sovereign bond holdings is confirmed. Over the entire sample period, larger predicted shares of low-risk government bonds reduced CDS spreads of banks whereas larger predicted shares of high-risk government bonds increased those spreads. Like the effects reported for $z$-scores before, the coefficient on high-risk sovereign bonds is around 70 times as large in terms of magnitudes compared to the coefficient on low-risk sovereign bonds. In contrast to the baseline effects, the separate estimation of different time periods shows that larger shares of risky government bonds increased bank risk already before the outbreak of the sovereign debt crisis.

Second, we show in the right-hand panel of Table 12 results of probit regressions explaining the likelihood that a bank has non-performing loans in the highest decile in a given year. High NPL ratios relative to all other banks ensures that this measure of risk is not much affected by business cycle effects or changes in prudential definitions over time. The effect of predicted sovereign debt shares is qualitatively identical to those reported before. Low risk government bonds reduce the likelihood for a bank to be among the bottom $10 \%$ of banks in terms of non-performing loan shares. Holding larger shares of high risk bonds, in turn, increases bank risk as measured by NPL ratios. The point estimates are estimated sufficiently precise for the full period, but turn mostly insignificant in the sub-periods.

Contrary to the regressions explaining $z$-scores, we now also find that a number of bankspecific covariates exhibit significant effects. Larger, better capitalized, and more profitable banks are less likely to have high relative shares of non-performing loans. The result that higher cost-to-income ratios also reduce this likelihood may indicate that banks spending more for information collection, reduce credit default risks. Consistent with such an explanation that more conservative bank business models are also less risky, we find that a larger share of retail as opposed to capital market funding also reduced the odds to be among the $10 \%$ of banks with most non-performing loans.

In sum, we confirm our main results that larger shares of risky sovereign debt increase bank risk for both CDS as a market-based, forward looking measure of risk as well as the NPL indicator as a measure of relative credit risk.

\section{Conclusions}

The financial crisis illustrated the need to understand the determinants of sovereign bond holdings by banks and whether these exposures correlate with banks' risk. We test whether such a nexus between sovereign debt and bank risk exists using detailed bank-level panel data on the sovereign bond holdings of all German banks on a country-by-country basis during the period from Q4:2005 until Q3:2013.

Contrary to prior literature, we account explicitly for the self-selection into holding sovereign debt. Conditional on the determinants of sovereign bond holdings, we categorise 
predicted holdings into low, medium, and high risk to explain the variation in measures of bank risk. The latter are based on annual prudential supervisory financial data between 2005 and 2012. Our research has three main findings:

First, we document a large degree of heterogeneity in sovereign bond holdings across banks. Many banks do not invest in sovereign bonds at all. The volume of bonds and the degree of diversification of sovereign bond portfolios differ across banking groups as well. This underpins the potential bias in previous studies of the relationship between sovereign debt exposures of banks and their risk when not accounting for the self-selection of banks into sovereign debt holdings. We find that larger, less well-capitalised (and in this sense riskier), and more affine to capital markets hold more sovereign bonds. For the full sample, the effects of these factors are largely stable over time. Bank-level determinants of sovereign exposures change over time in particular for the commercial and mortgage banks. Prior to the crisis, sovereign debt holdings of commercials were driven by larger cash holdings, a retail lending focus, and more efficient operations whereas stronger wholesale funding orientation and reliance on interest rather than fee income had a significant impact after the sovereign crisis. Likewise, mortgage banks with more leverage and higher return on equity together with larger cash holdings and less reliance on capital markets for refinancing exhibited larger sovereign debt holdings prior to the crisis. After the crisis, these aspects had no significant impact anymore whereas a generally larger share of securities in total assets also correlated with larger sovereign bond holdings. Overall, these changes may indicate changes in business models that were induced in particular for these banking groups.

Second, banks have reacted to changing macroeconomic factors only since the collapse of Lehman Brothers. Before the financial crisis, banks did not differentiate much between countries based on macroeconomic factors. Afterward, banks have restructured their sovereign bond portfolios according to macroeconomic fundamentals. German banks held more high-yield bonds, bonds from large countries, countries with low inflation, and from eurozone countries that were not subject to an IMF program. With the outbreak of the sovereign debt crisis in 2010, the effect of macroeconomic variables changed. Banks increasingly invested into bonds from countries with low levels of government debt over GDP. Likewise, lower yields made sovereign debt more attractive, thus exhibiting opposite effects compared to the period after Lehman but before 2010. These results reflect the changing perceptions of macroeconomic risks on sovereign bond markets.

Third, predicted shares of sovereign bond holdings affected bank risk. We use three measures of bank risk, the $z$-score, CDS spreads, and non-performing loans, and find that larger exposures to risky government debt increase also the riskiness of the average bank. This effect is particularly relevant after the outbreak of the sovereign debt crisis, and it is driven by the group of commercial banks. Thus, the evidence confirms the existence of a nexus between government debt and bank risk even in an economy that has not been hit directly by a sovereign debt crisis. 


\section{References}

Acharya, V V, and S Steffen (2015). The "Greatest" Carry Trade Ever? Understanding Eurozone Bank Risks. Journal of Financial Economics 115, 215-236.

Acharya, V, I Drechsler and P Schnabl (2014). A Pyrrhic Victory? Bank Bailouts and Sovereign Credit Risk. Journal of Finance 69(9), 2689-2739.

Alter, A. and A. Beyer (2014). The dynamics of spillover effects during the European sovereign debt turmoil. Journal of Banking and Finance 42, 134-153.

Alter, A. and Y. S. Schüler (2012). Credit spread interdependencies of European states and banks during the financial crisis. Journal of Banking and Finance 36, 3444-3468.

Amann, M, M Baltzer and M Schrape (2012). Microdatabase: Securities Holdings Statistics. Deutsche Bundesbank Technical Documentation. Frankfurt a.M.

Ang, A., F. A. Longstaff (2013). Systemic sovereign credit risk: Lessons from the U.S. and Europe. Journal of Monetary Economics 60(5), 493-510.

Angeloni, C and G B Wolff (2012). Are banks affected by their holdings of government debt? Bruegel Working Paper 2012/07. Brussels.

Bai, J, C Julliard and K Yuan (2012). Eurozone Sovereign Bond Crisis: Liquidity or Fundamental Contagion. Working paper.

Battistini, N., Pagano, M., Simonelli, S. (2014), Systemic risk, sovereign yields and bank exposure in the euro crisis, Economic Policy, April: 203-251.

Beber, A, M W Brandt and K A Kavajecz (2009). Flight-to-Quality or Flight-to-Liquidity? Evidence from the Eurozone Bond Market. Review of Financial Studies 22(3): 925957.

Beck, T (2008). Bank competition and financial stability: Friends or foes? World Bank Policy Research Working Paper 4656. Washington DC.

Becker, B., and V. Ivashina. 2014. Financial Repression in the European Sovereign Debt Crisis. Working Paper.

Behn M. Haselmann R. Kick, T., Vig, V. (2014). The Political Economy of Bank Bailouts. Working paper.

Bolton, P and O Jeanne (2011). Sovereign Default Risk and Bank Fragility in Financially Integrated Economies. National Bureau of Economic Research (NBER) Working Paper 16899. Cambridge MA.

Boot, W.A. and L. Ratnovski (2015). Banking and trading. Mimeo.

Buch, C M, C T Koch and M Koetter (2011). Size, Productivity, and International Banking. Journal of International Economics 85: 329-334.

Crosignani, M. (2014). Why are banks not recapitalized during crises? A political economy explanation. NYU Working Paper.

de Grauwe, Paul and Yuemei Yi (2012). Mispricing of sovereign risk and multiple equilibria in the Eurozone. Centre for European Policy Working Paper 361.

Fiorentino, E, C Koch and W Rudek (2010). Technical Documentation Microdatabase: External Position Reports of German Banks. Deutsche Bundesbank. Technical Documentation. Frankfurt a.M. 
Gennaioli, N, A Martin and S Rossi (2014). Sovereign Default, Domestic Banks and Financial Institutions. Journal of Finance 69(2), 819-866.

Heckman, J J (1979). Sample Selection Bias as a Specification Error. Econometrica 47 (1): 153-161.

Hildebrand, T, J Rocholl, and A Schulz (2012). Flight to Where? Evidence from Bank Investments During the Financial Crisis. Mimeo.

Huang, R. and Ratnovski, L. (2011). The Dark Side of Bank Wholesale Funding Journal of Financial Intermediation 20, 248-263.

Koetter, M. (2013). Market structure and competition in German banking. German Council of Economic Advisors Working Paper 06/2013. Wiesbaden.

Koetter, M. and Poghosyan, T. (2009). The identification of technology regimes in banking: Implications for the market power-fragility nexus. Journal of Banking and Finance 33, 1413-1422.

Krahnen, J. P. and R.H. Schmidt (2004). The German Financial System. Oxford University Press.

Laeven, L and Levine, R (2009). Bank governance, regulation and risk taking. Journal of Financial Economics 93: 259-275.

Loutskina, E and Strahan, P E (2015). Financial Integration, housing and economic volatility, Journal of Financial Economics 115(1), 25-41.

Rochet, J-C (2008). Why are there so many banking crises? In: The Politics and Policy of Bank Regulation. Princeton University Press. Princeton.

Sapienza, P. (2004). The Effects of Government Ownership on Bank Lending. Journal of Financial Economics 72, 357-384. 


\section{Data definitions and sources}

\section{$\underline{\text { Sovereign bond portfolios }}$}

Exposure to sovereign bonds EXP: this is a dummy variable which is equal to one if the bank $i$ holds sovereign bonds of country $j$ in quarter $t$ and zero otherwise. The information is based on the Securities Holdings Statistics of the Deutsche Bundesbank.

Sovereign Bond Holdings SOV: market value of a bank's sovereign bond holdings of sovereign $j$ in quarter $t$. Data are obtained from the Securities Holdings Statistics of the Deutsche Bundesbank. Individual security data are aggregated to the issuer country level by summing up over all ISINs per country, bank and quarter. Issuers at all levels of the government - central, federal and municipal - are included. Only securities held on banks' own accounts are included and data cover sovereign bonds held in the banking book and in the market book.

Predicted volume of risk sovereign bonds: this variable is used as a regressor in the equations explaining bank risk (Table 10-12). It is the predicted value of banks' investment in sovereign bonds from the model for the intensive margin in Table 5. The data are aggregated at the bank level and measured relative to total assets. Sovereign bond holdings are categorised into low, intermediate, and high-risk bonds according to the country classifications in Table 13. The risk measure is based on the average of the ratings by Moody's, Fitch and Standard and Poor's. Low risk is defined as AAA, intermediate risk is defined as AA and A, and high risk as BBB or worse.

\section{$\underline{\text { Bank-level variables }}$}

Total assets: log of total assets of the bank. Data is taken from the Monthly Balance Sheet Statistics of the Deutsche Bundesbank. It is a measure for bank size.

Cash \& overnight / total assets: ratio of cash and overnight interbank loans to total assets. Information is taken from the annual financial statements submitted by banks to the Deutsche Bundesbank. This variable reflects the liquid assets holdings of a bank (excluding sovereign bonds).

Customer loans / total loans: ratio of claims on customers to the sum of claims on customers and on banks. Information is taken from the annual financial statements submitted by banks to the Deutsche Bundesbank. This variable reflects the degree of retail orientation of a bank.

Security portfolio / total assets: ratio of bonds and stocks portfolio to total assets. Information is taken from the annual financial statements submitted by banks to the Deutsche Bundesbank. This variable reflects the importance of securities trading in the business model of banks.

Core capital ratio: ratio of equity capital minus deficit to total assets. Information is taken from the annual financial statements submitted by banks to the Deutsche Bundesbank. This variable reflects the risk-bearing capacity of banks.

Retail deposits / total assets: ratio of overnight deposits from household and non-financial firms to total assets. Information is taken from the monthly balance sheet statistics of the Deutsche Bundesbank.

Securitized liabilities / total assets: ratio of securitized liabilities to total assets. Securitized liabilities include covered bonds, money market papers and other securitized liabilities. Information is taken from the annual financial statements submitted by banks to the Deutsche Bundesbank.

Return on equity: ratio of total revenue to equity capital. The data are obtained from the annual financial reports and the annual profit and loss statements of the Deutsche Bundesbank.

Cost-to-income ratio: ratio of total operating costs to total operating revenue. Information is taken from the annual profit and loss statements of banks submitted to the Deutsche Bundesbank. 
Fee income / interest income: ratio of net fee income over net interest income. Net interest income is obtained by subtracting the interest expenses from the interest income. Information is taken from the annual profit and loss statements of banks submitted to the Deutsche Bundesbank.

Z-score: $z$-score, defined as (return on assets plus capital over assets) divided by the volatility of return on assets. In order to obtain a bank-time specific measure for volatility of $R o A$, we regress $R o A$ on bank and time fixed effects. The residuals of this regression give the volatility of $R o A$ of bank $\mathrm{i}$ in year $\mathrm{t}$ that cannot be explained by bank or time common effects. The residuals are winsorized and taken in absolute terms as measure for $\sigma_{R o A}$. The $z$-score is a measure of the distance to insolvency of a bank and thus an inverse measure for bank risk. A higher $z$-score indicates less risk. The $z$-score is winsorized at the $0.1 \%$ and $99.9 \%$ level to account for extreme outliers. The data are confidential bank supervisory data of the Deutsche Bundesbank and drawn from the annual financial reports and the annual profit and loss statements.

$N P L$ ratio: NPL ratio is an indicator equal to one if the bank belongs to the highest decile of non performing loans to total loans banks in a given year. Using such a relative measure, high NPL ratio relative to all other banks, instead of a continuous share of NPL abstracts from business cycle movements and avoids contamination by statistical breaks in prudential definitions over time. Information is taken from the annual financial statements submitted by banks to the Deutsche Bundesbank.

CDS spread: average quarterly quoted CDS spread on a bank with five-year maturity for senior unsecured debt with the complete restructuring clause and denominated in euro. Data is obtained from the data provider MarkIT.

\section{Country-level variables}

GDP: $\log$ of a country's GDP. Data are in constant prices as of the year 2005 and are seasonally adjusted. The quarterly time series has been extracted from the OECD database.

Sovereign debt ratio: percentage ratio of central government debt to GDP. The ratio is drawn from the OECD database and in quarterly frequency.

CPI inflation: inflation is measured through the consumer price index (CPI). All items are included in the consumer price index and the change against the same quarter of the previous year is calculated in $\%$. This quarterly time series has been extracted from the OECD database.

Sovereign bond yield: we take the average yield on 10-year sovereign bonds (in \%) obtained from Markit.

IMF measures: these data are obtained from the homepage of the IMF and include Extended Fund Facilities, Extended Arrangements, and Stand-by-Arrangements. We include a dummy variable which is equal to one from the time an IMF programme has been started, i.e. for Greece (from Q2:2010), Hungary (from Q2:2008), Ireland (Q4:2010), Mexico (Q2:2008), Poland (Q1:2013) and Portugal (Q2:2011).

Eurozone bond: dummy variable which is equal to one if the country is a member of the eurozone in the respective quarter and zero otherwise. This variable might capture preferential regulatory treatment of eurozone sovereign bonds as well as the absence of exchange rate risk.

\section{List of 29 included issuer countries}

AT, AU, BE, CA, CH, CZ, DE, DK, EE, ES, FI, FR, GR, HU, IE, IS, IT, JP, LU, MX, NL, NO, PL, PT, SE, SI, SK, UK, US. 


\section{Figure 1: Participation of German banks in the sovereign bond markets}

This figure gives the share of banks which are always active, never active or only in certain quarters active in sovereign bond markets. Activity is here defined as holding at least one sovereign bond in quarter t. A significant share of about $25 \%$ of German banks is always holding sovereign bonds. Slight changes in the percentage share of always and never active banks are induced by sample attrition.

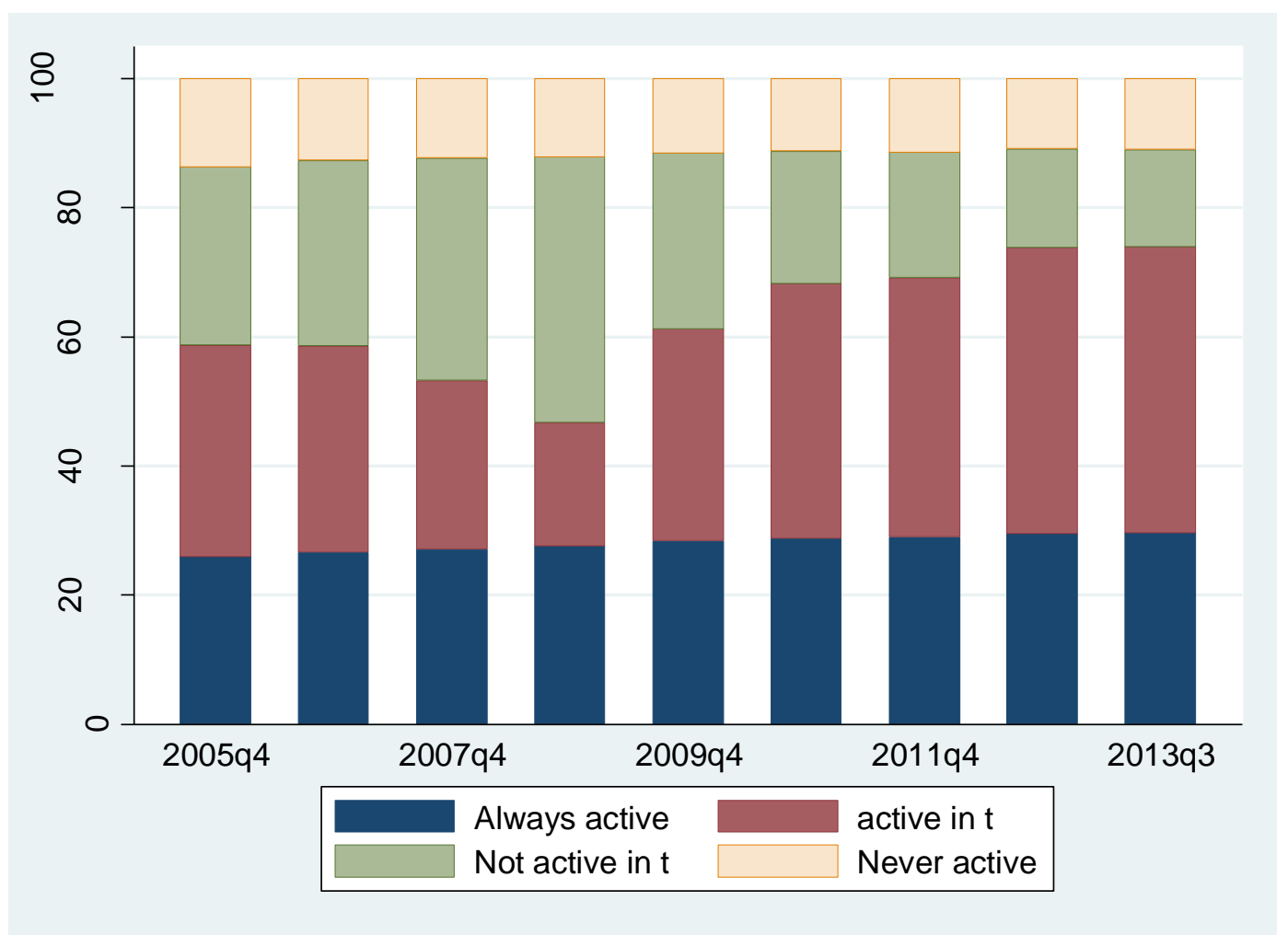

Source: Deutsche Bundesbank Securities Holdings Statistics; own calculations. 


\section{Figure 2: Participation rates in the sovereign bond markets by banking groups}

This figure shows the percentage share of banks (within each banking group) which hold a sovereign bond portfolio on their own accounts in the respective quarter. After the collapse of Lehman Brothers, the decreasing trend for cooperative and savings banks reverses. With the outbreak of the European sovereign crisis in 2010, the share of commercial banks engaged in sovereign bond markets rises as well.

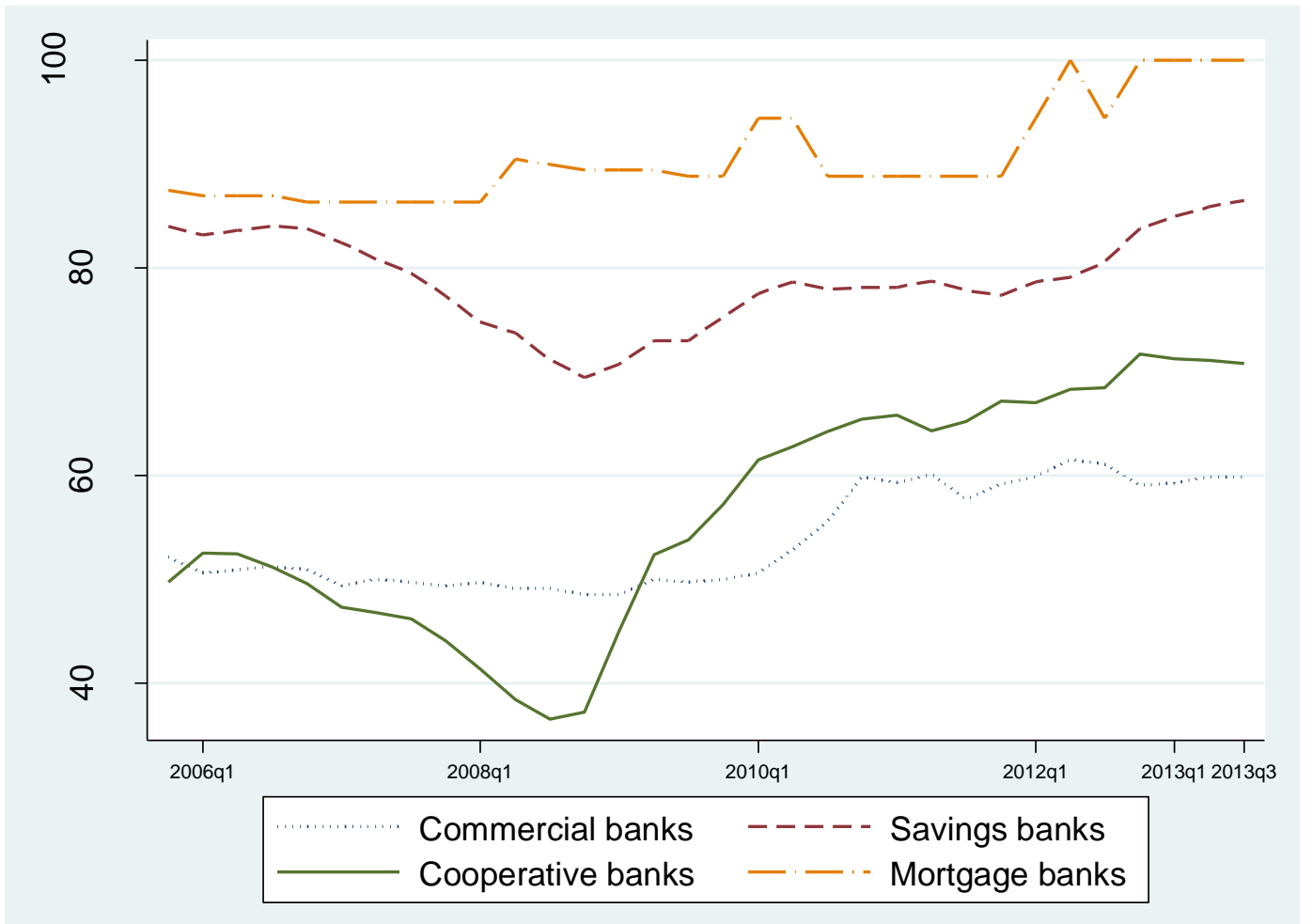

Source: Deutsche Bundesbank Securities Holdings Statistics; own calculations. 


\section{Figure 3: Share of sovereign bonds in balance sheets of banks}

This figure gives the average share of sovereign bond holdings in total assets (in \%) for each banking group. Sovereign bond holdings are decomposed by issuer, i.e. German sovereign bonds, sovereign bonds issued by eurozone periphery countries (GR, IT, IE, PT, ES), the remaining eurozone and the rest of the world. For a snapshot of these (and additional) variables at the latest available quarter, please see Table 4.

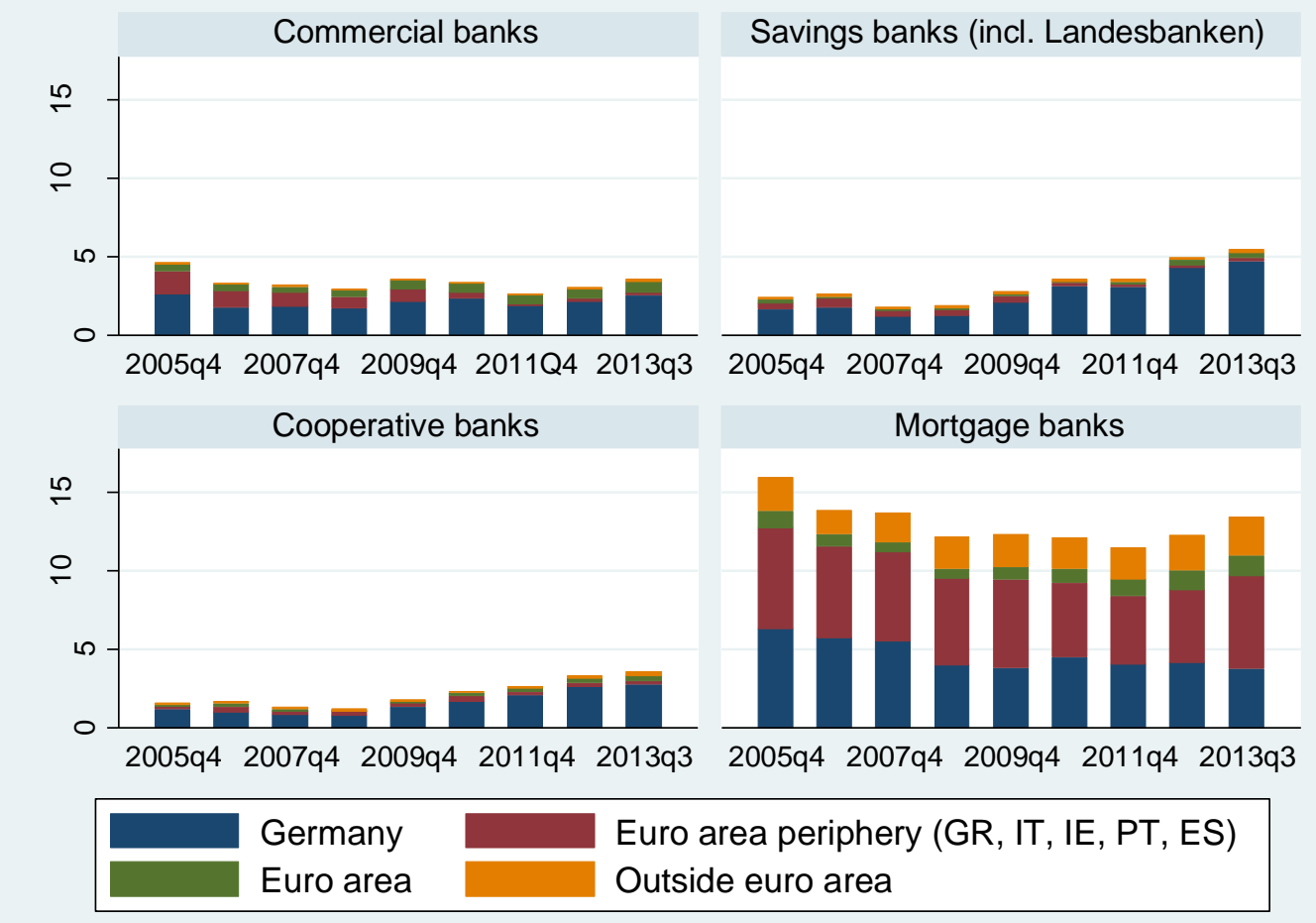

Source: Deutsche Bundesbank Securities Holdings Statistics; own calculations. 
Figure 4: Sovereign bond holdings of all German banks (2005-13)

Data plotted in this figure are aggregated over all banks located in Germany. The scale of the vertical axis varies in order to highlight changes in sovereign risk exposures.
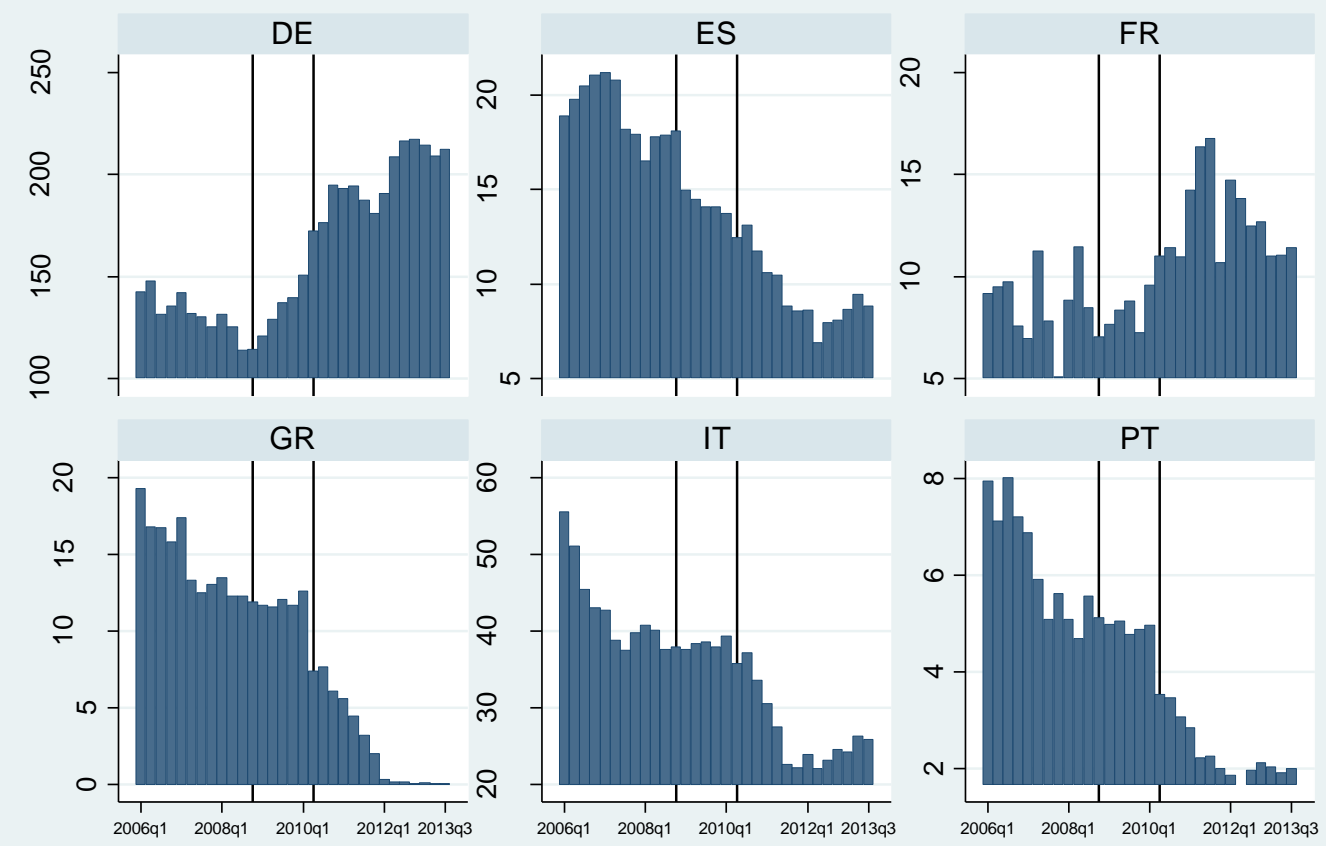

Note: The first vertical line marks the insolveny of Lehman Brothers in 2013 Q3, the second line the Greek rescue pachakges in 2010 Q2.

Source: Deutsche Bundesbank Securities Holdings Statistics; own calculations. 


\section{Figure 5: Average number of countries in the sovereign portfolio}

This figure gives the average number of issuer countries in the sovereign bond portfolio per banking group. There is relatively little variation over time but high variation between banks in each banking group.

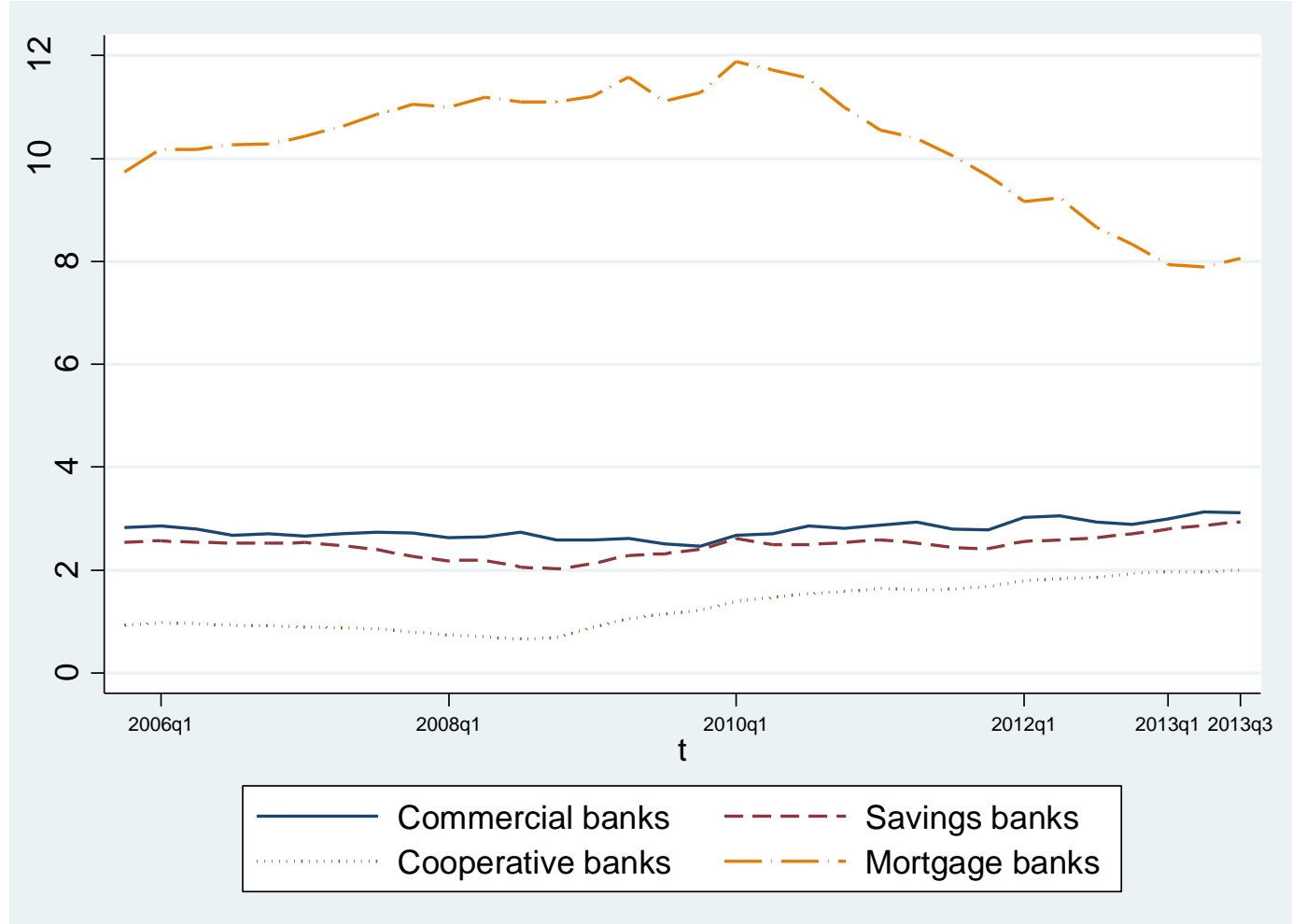

Source: Deutsche Bundesbank Securities Holdings Statistics; own calculations. 
Table 1: Descriptive statistics for macroeconomic variables

\begin{tabular}{|c|c|c|c|c|}
\hline & \multicolumn{2}{|c|}{$\begin{array}{l}\text { Selection equation } \\
1,632,540\end{array}$} & \multicolumn{2}{|c|}{$\begin{array}{c}\text { Outcome equation } \\
83,698\end{array}$} \\
\hline & Mean & Standard deviation & Mean & Standard deviation \\
\hline Holding sovereign bonds (dummy) & 0.05 & 0.22 & & \\
\hline Volume of sovereign bonds ( $€$ bn) & & & 0.1 & 0.65 \\
\hline Ln GDP & 0.56 & 1.92 & 21.02 & 1.74 \\
\hline Sovereign debt ratio & 0.59 & 0.36 & 0.62 & 0.27 \\
\hline CPI inflation & 0.03 & 0.02 & 0.02 & 0.02 \\
\hline Sovereign bond yield & 0.04 & 0.02 & 0.04 & 0.02 \\
\hline IMF measures & 0.07 & 0.25 & 0.08 & 0.27 \\
\hline Eurozone bond & 0.47 & 0.50 & 0.77 & 0.42 \\
\hline
\end{tabular}

Descriptive statistics for complete observations of macro covariates in the selection and outcome equations. The sample covers the period from Q4:2005 to Q3:2013, 1,970 banks, and 29 destination countries. 
Table 2: Descriptive statistics for bank-level variables

\begin{tabular}{l|c|c|cc}
\hline \hline & \multicolumn{2}{|c|}{$\begin{array}{c}\text { Selection equation } \\
1,632,540 \\
\end{array}$} & \multicolumn{2}{c}{ Outcome equation } \\
& Mean & Standard deviation & Mean & Standard deviation \\
\hline Ln total assets & 13.09 & 1.55 & 14.33 & 2.23 \\
Cash \& overnight / total assets & 0.07 & 0.07 & 0.05 & 0.05 \\
Customer loans / total loans & 0.80 & 0.16 & 0.77 & 0.17 \\
Security portfolio / total assets & 0.23 & 0.12 & 0.28 & 0.12 \\
Capital ratio & 0.06 & 0.05 & 0.05 & 0.03 \\
Retail deposits / total assets & 0.24 & 0.48 & 0.22 & 0.56 \\
Securitized liabilities / total assets & 0.03 & 0.06 & 0.07 & 0.13 \\
Return on equity & 0.04 & 0.09 & 0.03 & 0.14 \\
Cost-to-income ratio & 0.97 & 0.18 & 0.84 & 0.19 \\
Fee income / interest income & 0.47 & 4.64 & 0.36 & 2.88 \\
\hline \hline
\end{tabular}

Descriptive statistics for complete observations of bank-level covariates in the selection and outcome equations. The sample covers the period from Q4:2005 to Q3:2013, 1,970 banks, and 29 destination countries. The high standard deviation of the variable fee income / interest income is driven by few banks with an exceptionally high share of fee income relative to interest income. Our results are robust against eliminating these outliers by winsorizing the variable at the $1 \%$ level. 
Table 3: Descriptive statistics bank variables risk regressions

\begin{tabular}{lcc|c}
\hline \hline & Mean & Standard deviation & Observations \\
\hline Z-score & 3.56 & 1.20 & 6,907 \\
CDS spread & 111.97 & 138.81 & 416 \\
NPL ratio & 29.03 & 45.32 & 6,778 \\
\hline Ln total assets & 13.51 & 1.61 & 6,907 \\
Cash \& overnight / total assets & 0.06 & 0.06 & 6,907 \\
Customer loans / total loans & 0.80 & 0.16 & 6,907 \\
Security portfolio / total assets & 0.26 & 0.12 & 6,907 \\
Retail deposits / total assets & 0.34 & 0.10 & 6,907 \\
Securitized liabilities / total assets & 0.36 & 0.07 & 6,907 \\
Cost-to-income ratio & 0.82 & 0.09 & 6,907 \\
Fee over interest income & 0.48 & 0.10 & 6,907 \\
Volume of sovereign bonds with low risk (predicted) / & 0.04 & 0.20 & 6,907 \\
total assets & & & 6,907 \\
Volume of sovereign bonds with intermediate risk & 0.0009 & 0.007 & 6,907 \\
$\quad$ predicted) / total assets & & & \\
$\quad$ Volume of sovereign bonds with high risk (predicted) & 0.00006 & 0.0007 & \\
/ total assets & & & 6 \\
\hline \hline
\end{tabular}

Descriptive statistics for the regression sample for bank-level covariates in the bank risk equation. The sample is annual and includes 1,490 banks from 2006 until 2012. CDS spreads are used quarterly and are available for 24 German banks. Banks that hold sovereign bonds are included. 
Table 4: Importance of the security portfolio in the balance sheet of German banks

\begin{tabular}{c|c|c|c|c|c|}
\hline \hline & $(1)$ & $(2)$ & $(3)$ & $(4)$ & $(5)$ \\
& $\begin{array}{c}\text { Total assets } \\
\text { (billion } €)\end{array}$ & $\begin{array}{c}\text { Securities } \\
\text { (billion } €)\end{array}$ & $\begin{array}{c}\text { Sovereign Bonds } \\
\text { (billion } €)\end{array}$ & $\begin{array}{c}\text { Securities } \\
\text { (\% of total assets) }\end{array}$ & $\begin{array}{c}\text { Sovereign Bonds } \\
(\% \text { of total assets) }\end{array}$ \\
\hline Commercial banks & 2667.79 & 289.95 & 92.78 & 10.87 & 3.48 \\
Savings Banks & 2270.88 & 486.43 & 116.89 & 21.42 & 5.15 \\
Cooperative banks & 1034.22 & 244.64 & 36.61 & 23.65 & 3.54 \\
Mortgage banks & 471.29 & 129.34 & 60.74 & 27.44 & 12.89 \\
All banks & 6444.18 & 1150.36 & 307.03 & 17.85 & 4.76 \\
\hline \hline
\end{tabular}

Column (1) displays aggregate assets per banking group. Column (2) displays aggregate securities (including shares, bonds, etc). Column (3) shows aggregate sovereign bonds held in the banking or in the market book. Column (4) shows the percentage share of the overall securities portfolio and column (5) the share of all sovereign bonds in total assets. The banking group savings banks comprises savings banks and Landesbanken. The banking group cooperative banks include cooperative banks and their head institutions. The row "all banks" comprises the aggregate German banking system. Data are for the third quarter of 2013. 
Table 5: Regression results for the extensive and the intensive margin

\begin{tabular}{|c|c|c|c|}
\hline & $\begin{array}{c}-1 \\
\text { Intensive margin } \\
\text { (Outcome) }\end{array}$ & $\begin{array}{c}-2 \\
\text { Extensive margin } \\
\text { (Selection) }\end{array}$ & $\begin{array}{c}-3 \\
\text { Marginal effects } \\
\text { (Selection) }\end{array}$ \\
\hline Ln GDP & $\begin{array}{c}2.046 * * * \\
(0.273)\end{array}$ & $\begin{array}{c}0.674 * * * \\
(0.072)\end{array}$ & $\begin{array}{c}0.019 * * * \\
(0.002)\end{array}$ \\
\hline Sovereign debt ratio & $\begin{array}{c}0.736 * * * \\
(0.117)\end{array}$ & $\begin{array}{c}0.304 * * * \\
(0.030)\end{array}$ & $\begin{array}{c}0.008 * * * \\
(0.001)\end{array}$ \\
\hline CPI inflation & $\begin{array}{c}4.776 * * * \\
(0.789)\end{array}$ & $\begin{array}{c}1.710 * * * \\
(0.211)\end{array}$ & $\begin{array}{c}0.045^{* * *} \\
(0.006)\end{array}$ \\
\hline Sovereign bond yield & $\begin{array}{c}-11.390 * * * \\
(0.612)\end{array}$ & $\begin{array}{l}-0.025 \\
(0.162)\end{array}$ & $\begin{array}{c}0.001 \\
(0.004)\end{array}$ \\
\hline IMF measures & $\begin{array}{c}-0.350 * * * \\
(0.042)\end{array}$ & $\begin{array}{c}-0.166 * * * \\
(0.011)\end{array}$ & $\begin{array}{c}-0.004 * * * \\
(0.000)\end{array}$ \\
\hline Eurozone bond & $\begin{array}{c}1.980 * * * \\
(0.1677)\end{array}$ & $\begin{array}{c}0.506 * * * \\
(0.0602)\end{array}$ & $\begin{array}{c}0.014 * * * \\
(0.001)\end{array}$ \\
\hline Ln total assets & $\begin{array}{c}0.787 * * * \\
(0.050)\end{array}$ & $\begin{array}{c}0.164 * * * \\
(0.002)\end{array}$ & $\begin{array}{c}0.004^{* * *} \\
(0.000)\end{array}$ \\
\hline Cash \& overnight / total assets & $\begin{array}{c}0.101 \\
(0.322)\end{array}$ & $\begin{array}{c}0.125 * * \\
(0.049)\end{array}$ & $\begin{array}{c}0.003 * * \\
(0.001)\end{array}$ \\
\hline Customer loans / total loans & $\begin{array}{c}0.093 \\
(0.138)\end{array}$ & $\begin{array}{c}-0.086 * * * \\
(0.017)\end{array}$ & $\begin{array}{c}-0.003 * * * \\
(0.000)\end{array}$ \\
\hline Security portfolio / total assets & $\begin{array}{c}4.968 * * * \\
(0.191)\end{array}$ & $\begin{array}{c}1.897 * * * \\
(0.018)\end{array}$ & $\begin{array}{c}0.051 * * * \\
(0.001)\end{array}$ \\
\hline Core capital / total assets & $\begin{array}{c}-2.670 * * * \\
(0.646)\end{array}$ & $\begin{array}{c}-1.019 * * * \\
(0.079)\end{array}$ & $\begin{array}{c}-0.019 * * * \\
(0.002)\end{array}$ \\
\hline Retail deposits / total assets & $\begin{array}{c}0.042 * * \\
(0.019)\end{array}$ & $\begin{array}{l}-0.000 \\
(0.006)\end{array}$ & $\begin{array}{c}0.000 * * * \\
(0.000)\end{array}$ \\
\hline Securitized liabilities / total assets & $\begin{array}{c}2.900 * * * \\
(0.003)\end{array}$ & $\begin{array}{c}1.040 * * * \\
(0.000)\end{array}$ & $\begin{array}{c}0.028 * * * \\
(0.000)\end{array}$ \\
\hline Return on equity & $\begin{array}{c}0.163 * * \\
(0.074)\end{array}$ & $\begin{array}{l}0.035^{*} \\
(0.020)\end{array}$ & $\begin{array}{c}0.001 * * \\
(0.001)\end{array}$ \\
\hline Cost-to-income ratio & $\begin{array}{c}0.042 \\
(0.060)\end{array}$ & $\begin{array}{l}-0.001 \\
(0.002)\end{array}$ & $\begin{array}{l}-0.000 \\
(0.000)\end{array}$ \\
\hline Fee over interest income & $\begin{array}{c}-0.010 * * * \\
(0.003)\end{array}$ & $\begin{array}{c}-0.003 * * * \\
(0.001)\end{array}$ & $\begin{array}{c}-0.000 * * * \\
(0.000)\end{array}$ \\
\hline Number of observations & 83,698 & $1,632,540$ & $1,632,540$ \\
\hline Inverse Mills ratio (IMR) & 3.106 & & \\
\hline $\begin{array}{l}\text { Standard deviation of IMR } \\
\text { Adjusted } \mathrm{R}^{2} \text { (incl. bank, country, time dummies) }\end{array}$ & $\begin{array}{c}0.0874 \\
0.75\end{array}$ & & \\
\hline
\end{tabular}

$\overline{\text { Table } 5 \text { gives regression results for estimating the determinants of banks' investments in sovereign bonds using a }}$ Heckman model. The log of bank $i$ 's sovereign bond holdings of country $j$ is the dependent variable in the outcome equation. An indicator equal to one when observing that bank $i$ holds bonds of country $j$ is the dependent variable in the selection equation. Fixed effects for banking group, time and country are specified in the selection equation. In the outcome equation, fixed effects for bank, time and country are included. The inverse Mills ratio (IMR) is obtained from the extensive margin and corrects for self-selection. The sample covers the period from Q4:2005 to Q3:2013. Marginal effects are calculated for the extensive margin. ***, **,* $=$ significant at the $1 \%, 5 \%, 10 \%$ level. Standard errors are shown in brackets. 


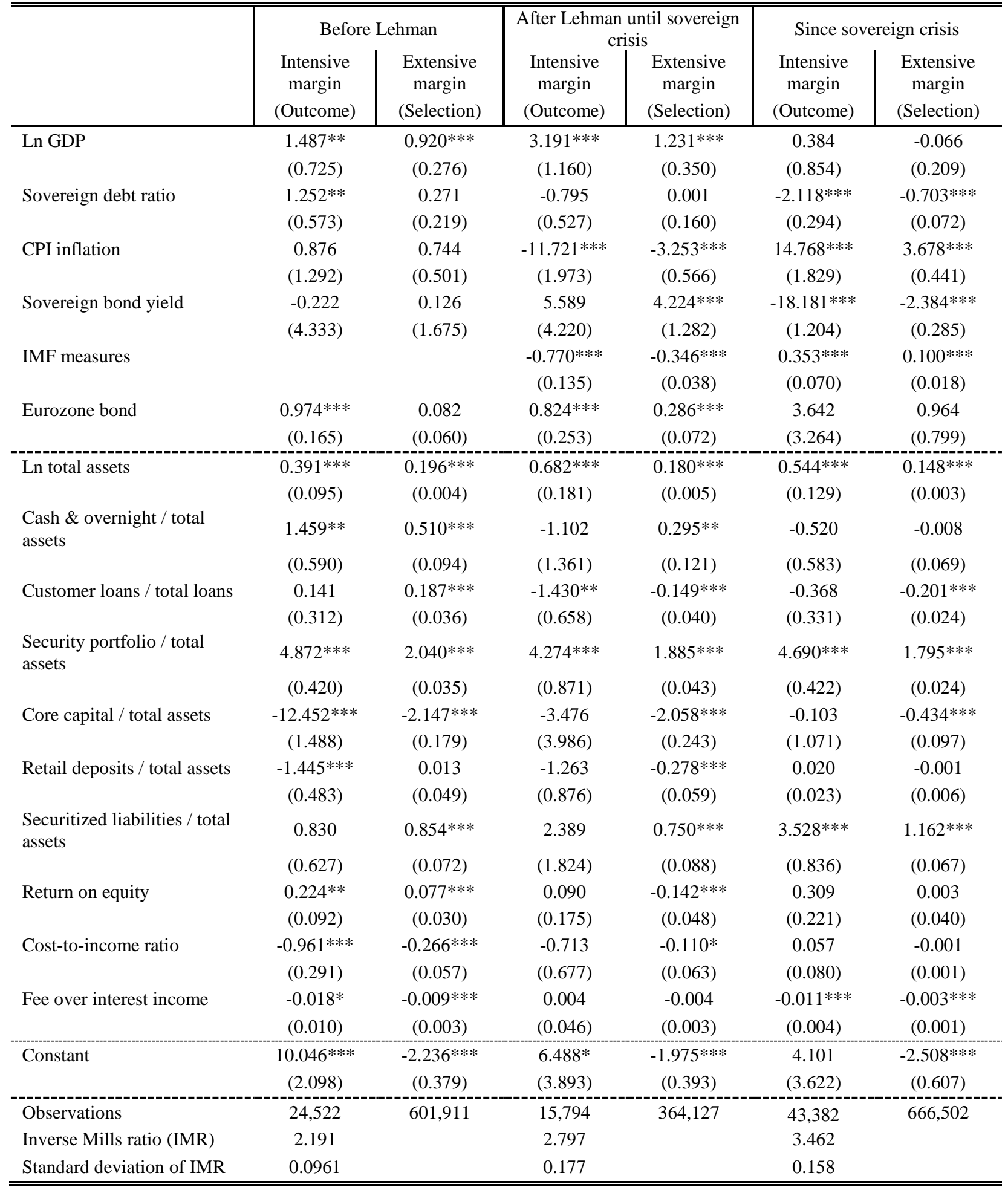

Table 6 gives regression results for estimating the determinants of banks' investments in sovereign bonds using a Heckman model and splitting the sample into the pre-Lehman (Q4:2005 to Q2:2008), the post-Lehman, preSovereign Crisis period (Q3:2008 to Q1:2010) and the since sovereign crisis period (Q2:2010 - Q3:2013). The $\log$ of bank $i$ 's sovereign bond holdings of country $j$ is the dependent variable in the outcome equation. An indicator equal to one when observing that bank $i$ holds bonds of country $j$ is the dependent variable in the selection equation. Fixed effects for banking group, time and country are specified in the selection equation. In the outcome equation, fixed effects for bank, time and country are included. The inverse Mills ratio (IMR) is obtained from the extensive margin and corrects for self selection. The sample covers the period from Q4:2005 to Q3:2013, 1,970 banks, and 29 destination countries. ***,**,* = significant at the 1\%, 5\%, $10 \%$ level. Standard errors are shown in brackets. 
Table 7: Sample splits by time period and banking group

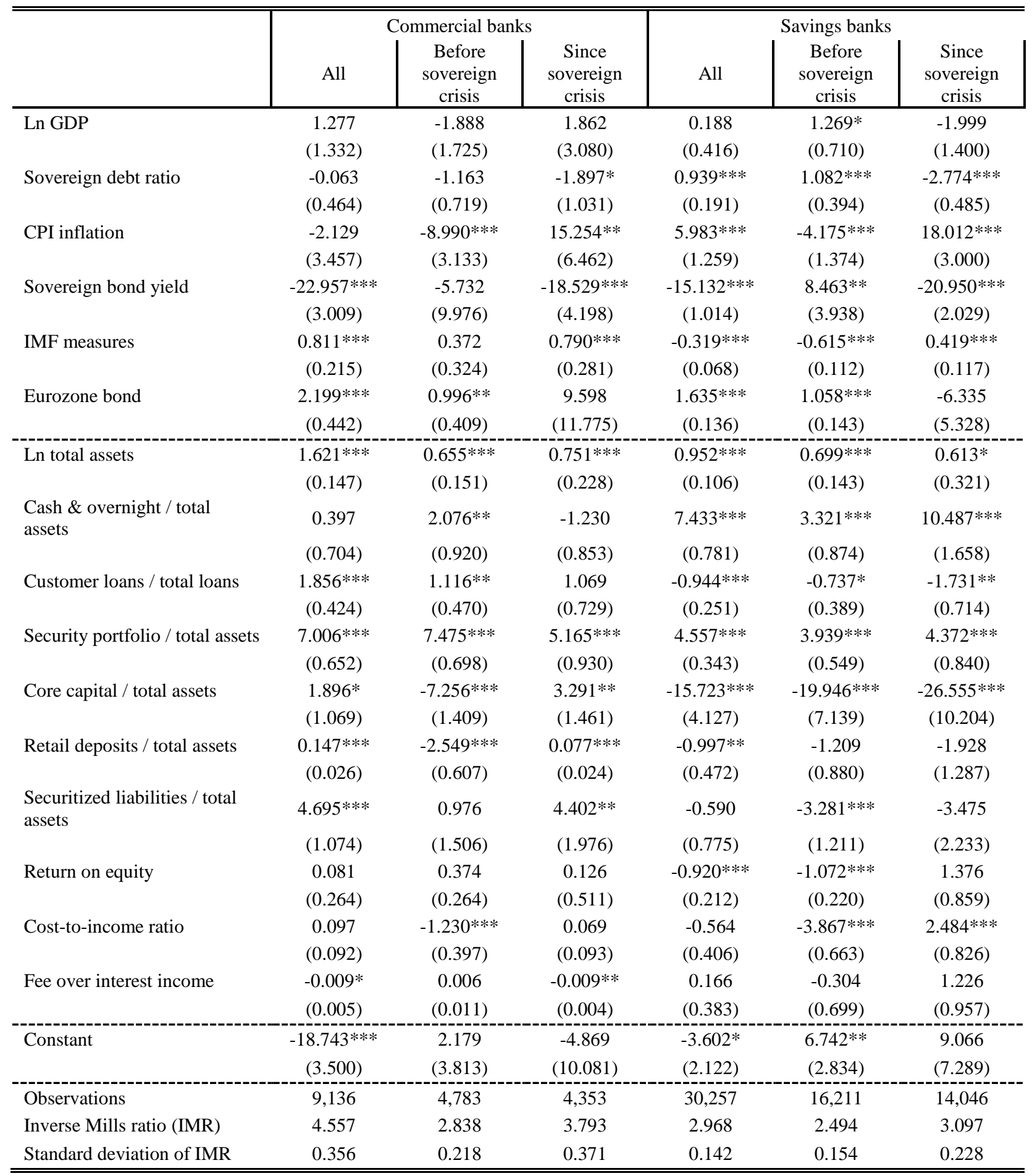


-- continued from previous page --

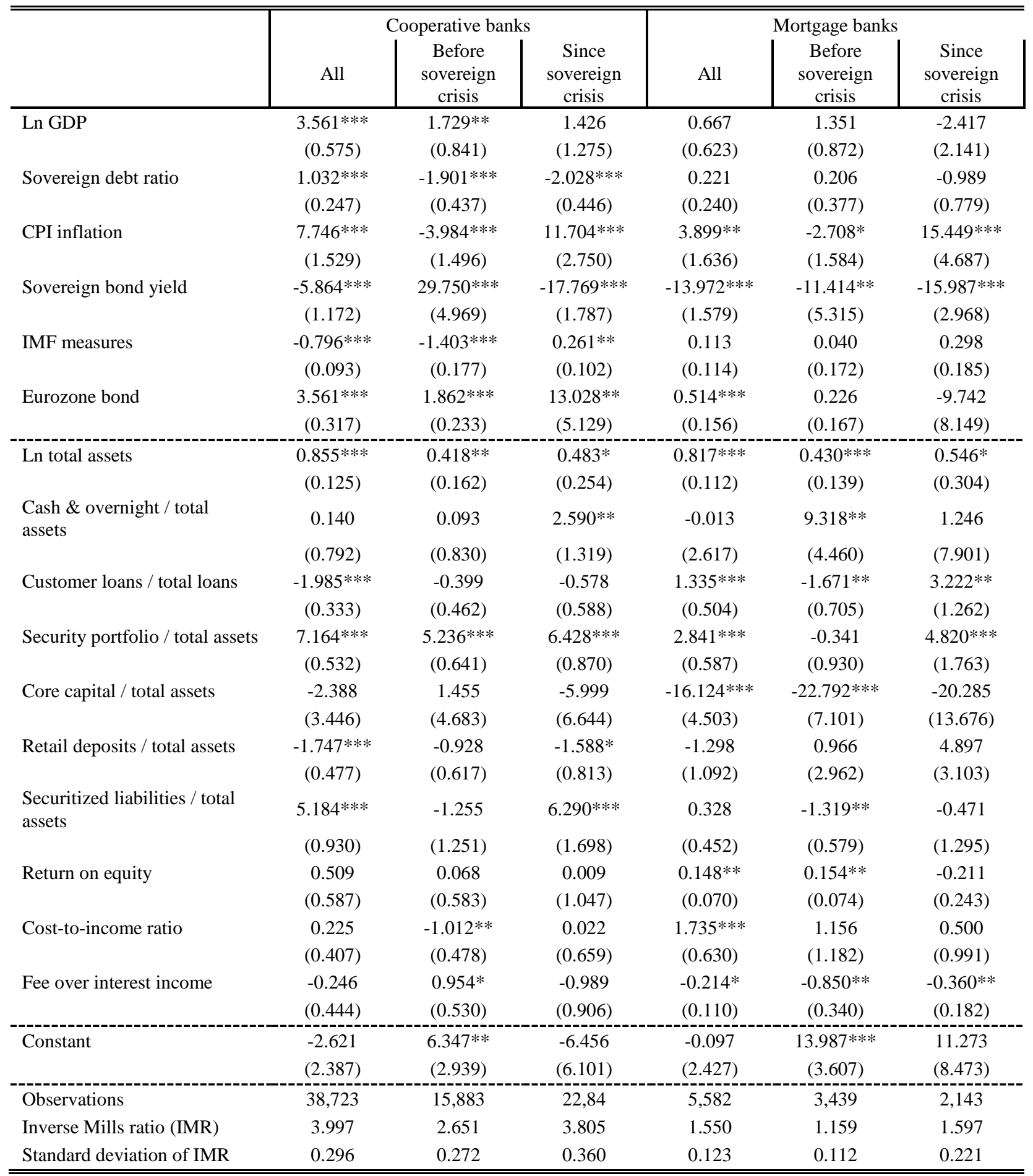

Table 7 gives regression results for estimating the determinants of banks' investments in sovereign bonds using a Heckman model and per banking group (commercial, saving, cooperative, and mortgage) and time period (total, pre- and since-outbreak of European sovereign debt crisis). For the sake of brevity we only report the outcome equation not the selection equation of the Heckman model. The log of bank $i$ 's sovereign bond holdings of country $j$ is the dependent variable in the outcome equation. Fixed effects for bank, time and country are included. The inverse Mills ratio (IMR) is obtained from the extensive margin and corrects for self- selection. The sample covers the period from Q4:2005 to Q3:2013, 1,970 banks, and 29 destination countries. ***, **, * = significant at the $1 \%, 5 \%, 10 \%$ level. Standard errors are shown in brackets. 
Table 8: Sample splits by issuer of sovereign bonds

\begin{tabular}{|c|c|c|c|c|}
\hline & $\begin{array}{c}\text { Non- } \\
\text { eurozone } \\
\text { bonds }\end{array}$ & Eurozone bonds & $\begin{array}{l}\text { Euro-periphery } \\
\text { bonds }\end{array}$ & German bonds \\
\hline Ln GDP & $\begin{array}{c}5.139 * * * \\
(0.535)\end{array}$ & $\begin{array}{c}2.400 * * * \\
(0.440)\end{array}$ & $\begin{array}{c}0.124 \\
(0.928)\end{array}$ & \\
\hline Sovereign debt ratio & $\begin{array}{c}1.051 * * * \\
(0.245)\end{array}$ & $\begin{array}{c}0.420 * * * \\
(0.123)\end{array}$ & $\begin{array}{c}0.542 * * \\
(0.214)\end{array}$ & \\
\hline CPI inflation & $\begin{array}{l}-2.044 * \\
(1.065)\end{array}$ & $\begin{array}{c}0.943 \\
(1.119)\end{array}$ & $\begin{array}{c}5.354 * * * \\
(2.027)\end{array}$ & \\
\hline Sovereign bond yield & $\begin{array}{c}-8.370 * * * \\
(2.500)\end{array}$ & $\begin{array}{c}-13.224 * * * \\
(0.757)\end{array}$ & $\begin{array}{c}-16.877 * * * \\
(1.257)\end{array}$ & \\
\hline IMF measures & $\begin{array}{c}-0.301 * * * \\
(0.054)\end{array}$ & $\begin{array}{l}-0.124 * \\
(0.068)\end{array}$ & $\begin{array}{l}-0.053 \\
(0.106) \\
\end{array}$ & \\
\hline Ln total assets & $\begin{array}{c}0.773 * * * \\
(0.087)\end{array}$ & $\begin{array}{c}0.684 * * * \\
(0.052)\end{array}$ & $\begin{array}{c}0.979 * * * \\
(0.129)\end{array}$ & $\begin{array}{c}0.561 * * * \\
(0.066)\end{array}$ \\
\hline Cash \& overnight / total assets & $\begin{array}{l}1.104 * \\
(0.572)\end{array}$ & $\begin{array}{c}0.220 \\
(0.325)\end{array}$ & $\begin{array}{c}-1.565 * * \\
(0.721)\end{array}$ & $\begin{array}{c}1.183 * * * \\
(0.345)\end{array}$ \\
\hline Customer loans / total loans & $\begin{array}{c}-0.507 * * \\
(0.225)\end{array}$ & $\begin{array}{l}0.274 * \\
(0.144)\end{array}$ & $\begin{array}{l}-0.418 \\
(0.290)\end{array}$ & $\begin{array}{c}0.538 * * * \\
(0.172)\end{array}$ \\
\hline Security portfolio / total assets & $\begin{array}{c}5.285^{* * *} \\
(0.423)\end{array}$ & $\begin{array}{c}4.313 * * * \\
(0.190)\end{array}$ & $\begin{array}{c}4.898 * * * \\
(0.684)\end{array}$ & $\begin{array}{c}3.074 * * * \\
(0.429)\end{array}$ \\
\hline Core capital / total assets & $\begin{array}{c}2.457 \\
(1.524)\end{array}$ & $\begin{array}{c}-4.132 * * * \\
(0.635)\end{array}$ & $\begin{array}{c}0.656 \\
(1.211)\end{array}$ & $\begin{array}{c}-4.099 * * * \\
(0.722)\end{array}$ \\
\hline Retail deposits / total assets & $\begin{array}{c}-2.667 * * * \\
(0.396)\end{array}$ & $\begin{array}{c}0.086 * * * \\
(0.014)\end{array}$ & $\begin{array}{c}-1.179 * * * \\
(0.444)\end{array}$ & $\begin{array}{c}0.111 * * * \\
(0.018)\end{array}$ \\
\hline Securitized liabilities / total assets & $\begin{array}{l}2.0 * * * \\
(0.005)\end{array}$ & $\begin{array}{l}2.7 * * * \\
(0.003)\end{array}$ & $\begin{array}{c}1.3 * \\
(0.007)\end{array}$ & $\begin{array}{l}1.7 * * * \\
(0.005)\end{array}$ \\
\hline Return on equity & $\begin{array}{c}0.141 \\
(0.106)\end{array}$ & $\begin{array}{l}0.153^{*} \\
(0.083)\end{array}$ & $\begin{array}{l}-0.177 \\
(0.138)\end{array}$ & $\begin{array}{c}0.160 \\
(0.136)\end{array}$ \\
\hline Cost-to-income ratio & $\begin{array}{c}-0.718 * * * \\
(0.238)\end{array}$ & $\begin{array}{c}0.108 * * \\
(0.054)\end{array}$ & $\begin{array}{c}-0.908 * * * \\
(0.289)\end{array}$ & $\begin{array}{c}0.135 * * * \\
(0.046)\end{array}$ \\
\hline Fee over interest income & $\begin{array}{c}0.032 * * \\
(0.014)\end{array}$ & $\begin{array}{c}-0.010 * * * \\
(0.003)\end{array}$ & $\begin{array}{l}-0.013 \\
(0.012) \\
\end{array}$ & $\begin{array}{l}-0.001 \\
(0.002)\end{array}$ \\
\hline Crisis I (August 2007) $(0 / 1)$ & $\begin{array}{c}-0.941 * * * \\
(0.136)\end{array}$ & $\begin{array}{c}-0.760 * * * \\
(0.104)\end{array}$ & $\begin{array}{c}-0.513^{* *} \\
(0.209)\end{array}$ & $\begin{array}{c}-0.433^{* * *} \\
(0.082)\end{array}$ \\
\hline Crisis II (September 2008) (0/1) & $\begin{array}{c}0.058 \\
(0.112)\end{array}$ & $\begin{array}{c}0.766 * * * \\
(0.076)\end{array}$ & $\begin{array}{c}0.841^{* * * *} \\
(0.192)\end{array}$ & $\begin{array}{c}0.754 * * * \\
(0.093)\end{array}$ \\
\hline Crisis III (2010) $(0 / 1)$ & $\begin{array}{c}-0.816^{* * *} \\
(0.147)\end{array}$ & $\begin{array}{c}0.251 * * * \\
(0.075)\end{array}$ & $\begin{array}{c}0.003 \\
(0.146)\end{array}$ & $\begin{array}{c}0.312 * * * \\
(0.071)\end{array}$ \\
\hline Constant & $\begin{array}{c}-4.348^{* *} \\
(1.872)\end{array}$ & $\begin{array}{c}6.771 * * * \\
(1.182)\end{array}$ & $\begin{array}{c}0.506 \\
(2.701)\end{array}$ & $\begin{array}{c}10.242 * * * \\
(1.385)\end{array}$ \\
\hline Observations & 19,524 & 64,174 & 17,377 & 30,297 \\
\hline IMR & 2.720 & 2.658 & 2.796 & 1.761 \\
\hline Standard deviation of IMR & 0.211 & 0.0812 & 0.399 & 0.277 \\
\hline
\end{tabular}

Table 8 gives regression results for estimating the determinants of banks' investments in sovereign bonds using a Heckman model by issuer of bonds. The log of bank i's sovereign bond holdings of country $\mathrm{j}$ is the dependent variable and we report only the outcome equation. In the outcome equation, fixed effects for bank, time and country are included. The crisis indicators equal one from 2007 Q3 (money market tensions), from Q3 :2008 (Lehman Brothers) and from Q2:2010 (sovereign crisis) onward and zero otherwise. The inverse Mills ratio (IMR) is obtained from the extensive margin and corrects for self-selection. The sample covers the period from Q4:2005 to Q3:2013, 1,970 banks, and 29 destination countries. ***, **, * = significant at the $1 \%, 5 \%, 10 \%$ level. Standard errors are shown in brackets. 
Table 9: Average risk measures per banking group and year

\begin{tabular}{|c|c|c|c|c|c|c|c|c|}
\hline & 2006 & 2007 & 2008 & 2009 & 2010 & 2011 & 2012 & Average \\
\hline Commercial banks & 3.08 & 2.75 & 2.99 & 3.48 & 3.22 & 2.40 & 2.80 & 2.94 \\
\hline Savings banks & 3.61 & 3.85 & 3.81 & 3.76 & 3.68 & 2.55 & 3.40 & 3.52 \\
\hline Cooperative banks & 3.60 & 4.12 & 3.86 & 4.02 & 3.87 & 2.94 & 3.58 & 3.66 \\
\hline Mortgage banks & 2.85 & 2.11 & 1.88 & 2.78 & 3.52 & 1.55 & 2.86 & 2.50 \\
\hline All & 3.55 & 3.87 & 3.72 & 3.85 & 3.75 & 2.76 & 3.46 & 3.54 \\
\hline \multicolumn{9}{|l|}{ (b) NPL ratio } \\
\hline & 2006 & 2007 & 2008 & 2009 & 2010 & 2011 & 2012 & Average \\
\hline Commercial banks & 0.08 & 0.12 & 0.11 & 0.18 & 0.11 & 0.14 & 0.13 & 0.13 \\
\hline Savings banks & 0.14 & 0.14 & 0.14 & 0.07 & 0.05 & 0.06 & 0.06 & 0.10 \\
\hline Cooperative banks & 0.08 & 0.08 & 0.06 & 0.11 & 0.10 & 0.10 & 0.11 & 0.09 \\
\hline Mortgage banks & 0.11 & 0.11 & 0.18 & 0.06 & 0.13 & 0.19 & 0.13 & 0.13 \\
\hline All & 0.10 & 0.11 & 0.10 & 0.10 & 0.09 & 0.09 & 0.10 & 0.10 \\
\hline \multicolumn{9}{|l|}{ (c) CDS spreads } \\
\hline & 2006 & 2007 & 2008 & 2009 & 2010 & 2011 & 2012 & Average \\
\hline Commercial banks & 14.35 & 28.00 & 86.62 & 103.59 & 105.49 & 169.59 & 225.14 & 105.80 \\
\hline Savings banks & 11.77 & 27.22 & 96.30 & 120.62 & 129.71 & 218.44 & 182.74 & 100.68 \\
\hline Cooperative banks & 19.83 & 44.16 & 126.76 & 161.08 & 140.71 & 158.29 & 173.43 & 126.83 \\
\hline Mortgage banks & 17.88 & 22.84 & 239.53 & 451.93 & 127.54 & 160.58 & 159.07 & 152.84 \\
\hline All & 14.00 & 28.24 & 114.19 & 165.93 & 124.03 & 185.74 & 190.66 & 112.61 \\
\hline
\end{tabular}

Table 9 shows the average bank risk measures per banking group and year. Panel shows the $z$-score which isis defined as return on assets plus capital over assets divided by the volatility of return on assets. Volatility is measured by the variation (in absolute terms) in RoA that cannot be explained by time and bank fixed effects. Panel (b) shows the average of the NPL-Indicator which equals 1 if a bank is within the $10 \%$ worst quantile of the non-performing loans to total loans distribution in a given year. Note that we define deciles on the basis of the entire population of banks, i.e. including those without sovereign exposures or missing data that precluded certain observations from the estimation sample. In this table we only show observations that are used in the regression though. Panel (c) shows the average CDS spread per banking group and year (averaged over quarters). See section 4.2 for a detailed description of the construction of the risk measures. Z-score and CDS spread are shown in absolute terms here but enter regressions in logs. 
Table 10: Baseline regressions explaining bank risk

\begin{tabular}{|c|c|c|c|}
\hline & All & $\begin{array}{c}\text { Before } \\
\text { sovereign crisis } \\
\end{array}$ & $\begin{array}{c}\text { Since sovereign } \\
\text { crisis } \\
\end{array}$ \\
\hline \multirow[t]{2}{*}{ Ln total assets } & $-0.079 * * *$ & -0.019 & -0.078 \\
\hline & $(0.029)$ & $(0.047)$ & $(0.099)$ \\
\hline \multirow[t]{2}{*}{ Cash \& overnight / total assets } & $-0.313^{*}$ & $-0.678 * *$ & -0.229 \\
\hline & $(0.179)$ & $(0.300)$ & $(0.308)$ \\
\hline \multirow[t]{2}{*}{ Customer loans / total loans } & -0.092 & -0.163 & 0.013 \\
\hline & $(0.084)$ & $(0.126)$ & $(0.200)$ \\
\hline \multirow[t]{2}{*}{ Security portfolio / total assets } & 0.134 & 0.037 & 0.096 \\
\hline & $(0.107)$ & $(0.185)$ & $(0.240)$ \\
\hline \multirow[t]{2}{*}{ Retail deposits / total assets } & -0.001 & -0.000 & -0.002 \\
\hline & $(0.001)$ & $(0.003)$ & $(0.003)$ \\
\hline \multirow[t]{2}{*}{ Securitized liabilities / total assets } & $-0.372 *$ & -0.033 & 0.505 \\
\hline & $(0.222)$ & $(0.430)$ & $(0.609)$ \\
\hline \multirow[t]{2}{*}{ Cost-to-income ratio } & 0.007 & 0.144 & -0.027 \\
\hline & $(0.115)$ & $(0.128)$ & $(0.182)$ \\
\hline \multirow[t]{2}{*}{ Fee over interest income } & -0.005 & 0.010 & -0.043 \\
\hline & $(0.025)$ & $(0.054)$ & $(0.033)$ \\
\hline \multirow[t]{2}{*}{ Volume of low risk sovereign bonds (predicted) / total assets } & 0.001 & $0.005 * *$ & $0.003 * *$ \\
\hline & $(0.001)$ & $(0.002)$ & $(0.001)$ \\
\hline \multirow[t]{2}{*}{ Volume of int risk sovereign bonds (predicted) / total assets } & 0.020 & -0.022 & -0.053 \\
\hline & $(0.030)$ & $(0.086)$ & $(0.038)$ \\
\hline \multirow[t]{2}{*}{ Volume of high risk sovereign bonds (predicted) / total assets } & 0.020 & 0.231 & $-0.811 * * *$ \\
\hline & $(0.122)$ & $(0.723)$ & $(0.268)$ \\
\hline \multirow[t]{2}{*}{ Constant } & $2.385^{* * *}$ & $1.527 * *$ & $2.377^{*}$ \\
\hline & $(0.409)$ & $(0.653)$ & $(1.346)$ \\
\hline Observations & 6,907 & 3,577 & 3,330 \\
\hline$R^{2}$ & 0.155 & 0.031 & 0.212 \\
\hline Number of banks & 1,490 & 1,177 & 1,258 \\
\hline
\end{tabular}

Table 10 shows panel regression results to explain bank risk. The dependent variable is the log of z-score of each bank where a higher value indicates lower risk. The sample is split into the before European sovereign crisis period (2006-09) and the period since the outbreak of the sovereign crisis (2010-12). Fixed effects for bank and time are included. Standard errors are clustered at the bank level and shown in brackets. $* * *, * *, *=$ significant at the $1 \%, 5 \%, 10 \%$ level. 
Table 11: Regressions explaining bank risk by banking group

\begin{tabular}{|c|c|c|c|c|c|c|c|c|c|}
\hline & \multicolumn{3}{|c|}{ Commercial banks } & \multicolumn{3}{|c|}{ Savings banks } & \multicolumn{3}{|c|}{ Cooperative banks } \\
\hline & All & $\begin{array}{c}\text { Before sovereign } \\
\text { crisis }\end{array}$ & $\begin{array}{c}\text { Since sovereign } \\
\text { crisis }\end{array}$ & All & $\begin{array}{c}\text { Before } \\
\text { sovereign crisis }\end{array}$ & $\begin{array}{c}\text { Since sovereign } \\
\text { crisis }\end{array}$ & All & $\begin{array}{c}\text { Before } \\
\text { sovereign crisis }\end{array}$ & $\begin{array}{c}\text { Since sovereign } \\
\text { crisis }\end{array}$ \\
\hline \multirow[t]{2}{*}{ Ln total assets } & $-0.111 * *$ & -0.028 & -0.202 & -0.074 & 0.121 & 0.021 & 0.021 & 0.078 & 0.112 \\
\hline & $(0.044)$ & $(0.070)$ & $(0.153)$ & $(0.068)$ & $(0.087)$ & $(0.417)$ & $(0.057)$ & $(0.099)$ & $(0.132)$ \\
\hline \multirow[t]{2}{*}{ Cash \& overnight / total assets } & -0.372 & -0.345 & -0.830 & 0.078 & 0.123 & -0.154 & -0.173 & $-0.774 * *$ & 0.268 \\
\hline & $(0.279)$ & $(0.579)$ & $(0.571)$ & $(0.343)$ & $(0.439)$ & $(0.893)$ & $(0.254)$ & $(0.379)$ & $(0.469)$ \\
\hline \multirow[t]{2}{*}{ Customer loans / total loans } & -0.063 & -0.151 & -0.648 & -0.037 & 0.056 & 0.022 & -0.009 & -0.084 & 0.187 \\
\hline & $(0.170)$ & $(0.223)$ & $(0.440)$ & $(0.162)$ & $(0.234)$ & $(0.493)$ & $(0.135)$ & $(0.236)$ & $(0.265)$ \\
\hline \multirow[t]{2}{*}{ Security portfolio / total assets } & -0.101 & -0.084 & -0.548 & -0.286 & -0.348 & 0.390 & 0.193 & 0.219 & 0.175 \\
\hline & $(0.209)$ & $(0.511)$ & $(0.338)$ & $(0.222)$ & $(0.327)$ & $(0.673)$ & $(0.156)$ & $(0.272)$ & $(0.351)$ \\
\hline \multirow[t]{2}{*}{ Retail deposits / total assets } & -0.002 & -0.002 & -0.006 & 0.001 & -0.002 & 0.002 & -0.000 & 0.003 & 0.001 \\
\hline & $(0.002)$ & $(0.005)$ & $(0.004)$ & $(0.003)$ & $(0.006)$ & $(0.008)$ & $(0.002)$ & $(0.004)$ & $(0.004)$ \\
\hline \multirow[t]{2}{*}{ Securitized liabilities / TA } & -0.384 & 0.244 & 1.284 & 0.438 & 1.445 & 2.090 & $-0.688^{*}$ & -0.958 & 0.245 \\
\hline & $(0.314)$ & $(0.632)$ & $(1.160)$ & $(0.522)$ & $(0.892)$ & $(1.705)$ & $(0.353)$ & $(0.700)$ & $(0.873)$ \\
\hline \multirow[t]{2}{*}{ Cost-to-income ratio } & 0.134 & $0.387^{*}$ & -0.371 & -0.268 & -0.022 & 0.691 & -0.010 & $0.353^{*}$ & 0.292 \\
\hline & $(0.148)$ & $(0.204)$ & $(0.272)$ & $(0.232)$ & $(0.350)$ & $(0.483)$ & $(0.130)$ & $(0.196)$ & $(0.266)$ \\
\hline \multirow[t]{2}{*}{ Fee over interest income } & 0.003 & -0.016 & -0.033 & -0.546 & -0.132 & $-1.391^{*}$ & 0.125 & $0.565^{*}$ & 0.351 \\
\hline & $(0.024)$ & $(0.048)$ & $(0.030)$ & $(0.341)$ & $(0.510)$ & $(0.751)$ & $(0.195)$ & $(0.314)$ & $(0.442)$ \\
\hline \multirow[t]{2}{*}{ Low risk sov holdings / TA } & 0.002 & $0.005 * *$ & 0.002 & $0.005^{*}$ & 0.001 & 0.001 & $0.005^{*}$ & -0.001 & $0.010 *$ \\
\hline & $(0.003)$ & $(0.002)$ & $(0.002)$ & $(0.003)$ & $(0.005)$ & $(0.003)$ & $(0.003)$ & $(0.006)$ & $(0.005)$ \\
\hline \multirow[t]{2}{*}{ Int risk sov holdings / TA } & $0.089 *$ & 0.079 & $-0.149 * * *$ & 0.093 & 0.113 & 0.238 & 0.031 & 0.686 & 0.161 \\
\hline & $(0.053)$ & $(0.070)$ & $(0.034)$ & $(0.095)$ & $(0.131)$ & $(0.343)$ & $(0.145)$ & $(0.555)$ & $(0.185)$ \\
\hline \multirow[t]{2}{*}{ High risk sov holdings / TA } & 0.249 & -0.459 & $-0.420 * * *$ & -0.549 & 3.599 & -0.030 & -0.926 & -0.370 & -0.900 \\
\hline & $(0.186)$ & $(0.828)$ & $(0.155)$ & $(0.797)$ & $(2.630)$ & $(1.806)$ & $(0.967)$ & (3.377) & $(1.270)$ \\
\hline \multirow[t]{2}{*}{ Constant } & $2.694 * * *$ & 1.313 & $5.052 * *$ & $2.716^{* * *}$ & -0.440 & 0.508 & 0.960 & -0.127 & -0.719 \\
\hline & $(0.644)$ & $(0.960)$ & $(2.202)$ & (1.024) & $(1.247)$ & $(6.307)$ & $(0.760)$ & $(1.330)$ & $(1.766)$ \\
\hline Observations & 542 & 284 & 258 & 2,309 & 1,331 & 978 & 3,946 & 1,894 & 2,052 \\
\hline$R^{2}$ & 0.143 & 0.209 & 0.116 & 0.229 & 0.021 & 0.328 & 0.151 & 0.073 & 0.190 \\
\hline Number of banks & 120 & 94 & 103 & 420 & 395 & 355 & 932 & 670 & 785 \\
\hline
\end{tabular}

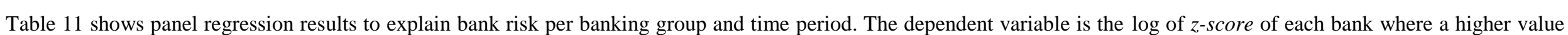

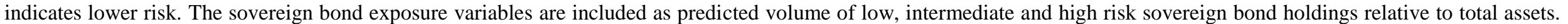
Fixed effects for bank and time are included. Standard errors are clustered at the bank level and shown in brackets. ***, **,* = significant at the $1 \%, 5 \%, 10 \%$ level. 
Table 12: Regressions explaining bank risk using alternative risk measures

\begin{tabular}{|c|c|c|c|c|c|c|}
\hline & & Regression of CDS spreads bankgroup and time FE & $\begin{array}{l}\text { oup and time FE } \\
\text { Since sovereign crisis }\end{array}$ & $\begin{array}{l}\text { Prob } \\
\text { All } \\
\end{array}$ & $\begin{array}{l}\text { gressions of NPL ratio } \\
\text { Before sovereign crisis }\end{array}$ & $\begin{array}{l}\text { arginal effects) } \\
\text { Since sovereign crisis }\end{array}$ \\
\hline Ln total assets & $\begin{array}{c}-0.063 * * * \\
(0.024)\end{array}$ & $\begin{array}{c}-0.070 * * * \\
(0.024)\end{array}$ & $\begin{array}{l}-0.068 \\
(0.043)\end{array}$ & $\begin{array}{c}-0.022 * * * \\
(0.005)\end{array}$ & $\begin{array}{c}-0.024 * * * \\
(0.006)\end{array}$ & $\begin{array}{c}-0.024 * * * \\
(0.006)\end{array}$ \\
\hline Cash \& overnight / total assets & & & & $\begin{array}{c}0.083 \\
(0.093)\end{array}$ & $\begin{array}{l}-0.133 \\
(0.132)\end{array}$ & $\begin{array}{c}0.158 \\
(0.116)\end{array}$ \\
\hline Customer loans / total loans & & & & $\begin{array}{c}0.011 \\
(0.044)\end{array}$ & $\begin{array}{c}0.039 \\
(0.053)\end{array}$ & $\begin{array}{c}0.012 \\
(0.055)\end{array}$ \\
\hline Security portfolio / total assets & & & & $\begin{array}{l}-0.022 \\
(0.051)\end{array}$ & $\begin{array}{l}-0.053 \\
(0.068)\end{array}$ & $\begin{array}{l}-0.076 \\
(0.059)\end{array}$ \\
\hline Core capital/ total assets & $\begin{array}{c}0.009 \\
(0.016)\end{array}$ & $\begin{array}{l}-0.010 \\
(0.017)\end{array}$ & & $\begin{array}{l}-0.476^{*} \\
(0.261)\end{array}$ & $\begin{array}{c}-2.556^{* *} \\
(1.001)\end{array}$ & $\begin{array}{l}-0.087 \\
(0.154)\end{array}$ \\
\hline Retail deposits / total assets & $\begin{array}{c}0.003 \\
(0.005)\end{array}$ & $\begin{array}{l}-0.006 \\
(0.006)\end{array}$ & $\begin{array}{c}0.006 \\
(0.004)\end{array}$ & $\begin{array}{c}-0.001 * * \\
(0.001)\end{array}$ & $\begin{array}{c}0.001 \\
(0.001)\end{array}$ & $\begin{array}{c}-0.003 * * * \\
(0.001)\end{array}$ \\
\hline Securitized liabilities / total assets & & & & $\begin{array}{c}0.037 \\
(0.137)\end{array}$ & $\begin{array}{c}0.020 \\
(0.137)\end{array}$ & $\begin{array}{c}0.065 \\
(0.185)\end{array}$ \\
\hline Return on equity & & & & $\begin{array}{c}-0.367 * * * \\
(0.095)\end{array}$ & $\begin{array}{c}-0.372 * * \\
(0.149)\end{array}$ & $\begin{array}{c}-0.285 * * * \\
(0.095)\end{array}$ \\
\hline Cost-to-income ratio & & & & $\begin{array}{c}-0.092 * * \\
(0.046)\end{array}$ & $\begin{array}{c}-0.258 * * \\
(0.113)\end{array}$ & $\begin{array}{c}-0.076^{* *} \\
(0.036)\end{array}$ \\
\hline Fee over interest income & & & & $\begin{array}{l}-0.015 \\
(0.011)\end{array}$ & $\begin{array}{l}-0.009 \\
(0.012)\end{array}$ & $\begin{array}{l}-0.022 \\
(0.014)\end{array}$ \\
\hline Low risk sovereign bonds (predicted) / TA & $\begin{array}{c}-0.004 * * \\
(0.002)\end{array}$ & $\begin{array}{l}-0.006 \\
(0.004)\end{array}$ & $\begin{array}{c}-0.004 * * * \\
(0.001)\end{array}$ & $\begin{array}{c}-0.002 * * * \\
(0.001)\end{array}$ & $\begin{array}{l}-0.000 \\
(0.001)\end{array}$ & $\begin{array}{c}-0.002 * * * \\
(0.001)\end{array}$ \\
\hline Int risk sovereign bonds (predicted) / TA & $\begin{array}{c}0.103^{* *} \\
(0.048)\end{array}$ & $\begin{array}{c}0.114 \\
(0.104)\end{array}$ & $\begin{array}{c}0.032 \\
(0.021)\end{array}$ & $\begin{array}{c}0.011 \\
(0.017)\end{array}$ & $\begin{array}{l}-0.011 \\
(0.030)\end{array}$ & $\begin{array}{c}0.010 \\
(0.018)\end{array}$ \\
\hline High risk sovereign bonds (predicted) / TA & $\begin{array}{l}0.272 * * \\
(0.108)\end{array}$ & $\begin{array}{c}1.493 * * * \\
(0.550)\end{array}$ & $\begin{array}{c}0.241 * * * \\
(0.085)\end{array}$ & $\begin{array}{c}0.165^{* *} \\
(0.080)\end{array}$ & $\begin{array}{l}-0.120 \\
(0.287)\end{array}$ & $\begin{array}{c}0.222 \\
(0.152)\end{array}$ \\
\hline Constant & $\begin{array}{c}3.773 * * * \\
(0.415)\end{array}$ & $\begin{array}{c}4.135 * * * \\
(0.472)\end{array}$ & $\begin{array}{c}6.448 * * * \\
(0.830)\end{array}$ & $\begin{array}{c}1.829 * * * \\
(0.634)\end{array}$ & $\begin{array}{c}3.548 * * * \\
(1.241)\end{array}$ & $\begin{array}{c}2.106 * * * \\
(0.775)\end{array}$ \\
\hline Observations & 416 & 257 & 159 & 6,778 & 3,487 & 3,291 \\
\hline$R^{2}$ (incl time and bankgroup $F E$ ) & 0.883 & 0.873 & 0.524 & & & \\
\hline
\end{tabular}

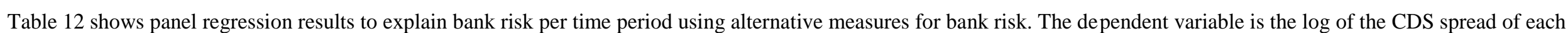
bank in the left panel of the table. Bankgroup and time fixed effects, which control for common financial market developments, are included. Robust standard errors are used. In

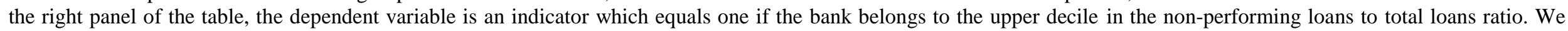

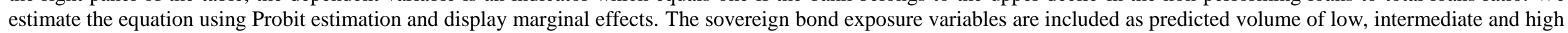
risk sovereign bond holdings relative to total assets. Standard errors are clustered at the bank level and shown in brackets. $* * *, * *, *=$ significant at the $1 \%, 5 \%, 10 \%$ level. 


\section{Table 13: List of countries by risk category}

\begin{tabular}{lll}
\hline \hline Low-risk sovereigns & Intermediate-risk sovereigns & High-risk sovereigns \\
Australia (AU) & Belgium (BE) & Greece (GR)*since Q2:2010 \\
Austria (AT) & Czech Republic (CZ) & Hungary (HU)*since Q4:2008 \\
Canada (CA) & France (FR)*since Q4:2012 & Iceland (IS)*since Q1:2009 \\
Denmark (DK) & Hungary (HU)*until Q3:2008 & Ireland (I.E.)*since Q3:2011 \\
Finland (FI) & Iceland (IS)*until Q4:2008 & Italy (IT)*since Q4:2012 \\
France (FR)*until Q3:2012 & Ireland (I.E.)*Q3:2009 until Q2:2011 & Mexico (MX) \\
Germany (DE) & Italy (IT)*until Q3:2012 & Portugal (PT)*since Q3:2011 \\
Ireland (I.E.)*until Q2:2009 & Greece (GR)*until Q1:2010 & Slovenia (SI)*since Q4:2012 \\
Luxembourg (LU) & Japan (JP) & Spain (ES)*since Q2:2012 \\
Netherlands (NL) & Korea (KR) & \\
Norway (NO) & Poland (PL) & \\
Spain (ES)*until Q1:2010 & Portugal (PT)*until Q2:2011 & \\
Sweden (SE) & Slovenia (SI)*until Q3:2012 & \\
Switzerland (CH) & Spain (ES)* Q2:2010 until Q1:2012 & \\
United Kingdom (UK)*until Q3:2012 & Slovak Republic (SK) & \\
United States (US) & United Kingdom (UK)*since Q4:2012 & \\
\hline \hline
\end{tabular}

Table 13 shows the included countries per risk category. The risk measure is based on the average of the ratings by Moody's, Fitch and Standard and Poor's. Low risk is defined as AAA, intermediate risk is defined as AA and A, and high risk as BBB or worse. An asterisk (*) indicates that sovereigns migrated from one category to another between 2005 and 2013. 
